\title{
Cyclic Lipopeptide Production by Plant-Associated Pseudomonas spp.: Diversity, Activity, Biosynthesis, and Regulation
}

\author{
Jos M. Raaijmakers, Irene de Bruijn, and Maarten J. D. de Kock \\ Laboratory of Phytopathology, Wageningen University, Binnenhaven 5, 6709 PD Wageningen, The Netherlands \\ Submitted 25 November 2005. Accepted 21 February 2006.
}

Cyclic lipopeptides (CLPs) are versatile molecules produced by a variety of bacterial genera, including plant-associated Pseudomonas spp. CLPs are composed of a fatty acid tail linked to a short oligopeptide, which is cyclized to form a lactone ring between two amino acids in the peptide chain. CLPs are very diverse both structurally and in terms of their biological activity. The structural diversity is due to differences in the length and composition of the fatty acid tail and to variations in the number, type, and configuration of the amino acids in the peptide moiety. CLPs have received considerable attention for their antimicrobial, cytotoxic, and surfactant properties. For plant-pathogenic Pseudomonas spp., CLPs constitute important virulence factors, and pore formation, followed by cell lysis, is their main mode of action. For the antagonistic Pseudomonas sp., CLPs play a key role in antimicrobial activity, motility, and biofilm formation. CLPs are produced via nonribosomal synthesis on large, multifunctional peptide synthetases. Both the structural organization of the CLP synthetic templates and the presence of specific domains and signature sequences within peptide synthetase genes will be described for both pathogenic and antagonistic Pseudomonas spp. Finally, the role of various genes and regulatory mechanisms in CLP production by Pseudomonas spp., including two-component regulation and quorum sensing, will be discussed in detail.

Additional keywords: Bacillus, nonribosomal peptide synthesis.

The genus Pseudomonas not only harbors plant- and humanpathogenic species, but also accommodates species that promote plant growth, degrade xenobiotic compounds, antagonize plant pathogenic fungi, or induce resistance in plants (Compant et al. 2005; Haas and Défago 2005; Pieterse et al. 2002; Ryu et al. 2003). The diverse life styles of Pseudomonas spp. and the complexity of their interactions with multiple hosts have been the subject of numerous molecular, biochemical, and ecological studies (Ramos 2004). Recently, whole genome sequences of multiple Pseudomonas strains representing various species have become available and allow a more in-depth study of metabolic pathways and regulatory networks as well as the exploration and exploitation of yet-unknown genes and gene products. The extensive interest in Pseudomonas spp. is due, in part, to the production of a wide variety of metabolites, including enzymes, volatiles, bacteriocins, toxins, antibiotics, and cyclic lipopeptides (Haas and Défago 2005; Raaijmakers et al. 2002).

Cyclic lipopeptides (CLPs) are versatile molecules with antimicrobial, cytotoxic, and surfactant properties. CLPs are produced by several plant-associated Pseudomonas spp., including pathogenic Pseudomonas syringae, $P$. tolaasii, $P$. fuscovaginae, $P$. corrugata, and P. fluorescens (Bender et al. 1999), and by multiple strains classified as antagonistic $P$. fluorescens and $P$. putida (Nielsen et al. 2002; Nybroe and Sørensen 2004). In a recent review by Nybroe and Sørensen (2004), several chemical and biological aspects of CLP production in fluorescent pseudomonads were described. Also, CLP production by plant-pathogenic $P$. syringae has been the subject of several reviews (Bender et al. 1999; Bender and Scholz-Schroeder 2004; Willis and Kinscherf 2004). The purpose of this review is to provide an up-to-date overview of the current knowledge of the structural diversity and activity of CLPs produced by plant-associated Pseudomonas spp., in particular the antagonistic Pseudomonas spp. A detailed description of genes involved in the regulation and biosynthesis of CLPs will be presented, with emphasis on specific domains and signature sequences within CLP biosynthetic templates. These analyses provide insights into the specificity-conferring codes in peptide synthetase genes of Pseudomonas spp. and allow a prediction of the final structure of the CLP molecule based on sequence data. Whenever necessary, comparisons will be made with CLPs of other bacteria and, in particular, with surfactin produced by Bacillus spp.

\section{Structural diversity.}

A variety of methods have been used to elucidate the primary and secondary structures of CLPs produced by bacteria (Ballio et al. 1996; Bare et al. 1999; De Souza et al. 2003; Henriksen et al. 2000; Koumoutsi et al. 2004; Monti et al. 2001; Nielsen et al. 1999, 2002; Sørensen et al. 2001). CLPs produced by Pseudomonas spp. are composed of a fatty acid tail linked to a short oligopeptide, which is cyclized to form a lactone ring between two amino acids in the peptide chain. Based on the length and composition of the fatty acid tail as well as the number, type, and configuration of the amino acids in the peptide moiety, CLPs of Pseudomonas spp. were classified into four major groups (i.e., the viscosin, amphisin, tolaasin, and syringomycin groups) (Table 1). In brief, the viscosin group harbors CLPs with 9 amino acids linked at the N-terminus to, in most cases, 3-hydroxy decanoic acid (3-HDA). Pseudomonas spp. producing CLPs in this group are from a variety of origins, including soil, rhizosphere, phyllosphere, and marine environments. For example, viscosin production has been de- 
scribed for pectolytic strains of $P$. fluorescens causing head rot of broccoli (Hildebrand et al. 1998) and for a Pseudomonas isolate obtained from a tube worm collected from a marine environment (Gerard et al. 1997). Similarly, massetolide A production originally was described for a yet-unidentified Pseudomonas sp. isolated from the surface of leafy red algae collected at $-15 \mathrm{~m}$ in the sea near the coast of British Columbia (Gerard et al. 1997), and later was described for a $P$. fluorescens strain isolated from the rhizosphere of wheat grown in a soil suppressive to take-all disease of wheat (De Souza et al. 2003). In a comprehensive survey, Nielsen and associates (2002) showed that, among the Pseudomonas spp. isolated from the rhizosphere of sugar beet, viscosin-like CLPs were produced primarily by strains belonging to $P$. fluorescens biovar I. Whether members of specific CLP groups are produced predominantly by specific biovars of fluorescent Pseudomonas spp. remains to be further investigated using large collections of isolates from different environmental origins.

CLPs in the amphisin group consist of 11 amino acids in the peptide part coupled to 3-HDA (Table 1). For several members of this group, including amphisin and tensin, the crystal structure has been resolved (Henriksen et al. 2000; Sørensen et al. 2001). For both tensin and amphisin, the structures are mainly helical, with the cyclic peptide wrapping around a water molecule. Based on the distance between two negatively charged residues of the molecule, Henriksen and associates (2000) suggested that tensin most likely cannot form complexes with $\mathrm{Ca}^{2+}$, as was shown for surfactin produced by Bacillus spp. (Peypoux et al. 1999). Crystallography further showed that, in amphisin, the 3-HDA fatty acid tail protrudes from the hydro- phylic side of the molecule (Nybroe and Sørensen 2004). For the $P$. fluorescens strains producing amphisin-like CLPs, Nielsen and associates (2002) identified several other interesting characteristics, including the production of chitinases and the volatile hydrogen cyanide ( $\mathrm{HCN})$, two traits that have been associated with biological control of plant-pathogenic fungi (Haas and Défago 2005; Whipps 2001). These traits and, in particular, $\mathrm{HCN}$ production were not common among the $P$. fluorescens strains producing viscosin-like CLPs (Nielsen et al. 2002).

Compared with the viscosin and amphisin groups, CLPs in the tolaasin group are much more diverse due to multiple variations in both the composition and length of the peptide chain (19 to 25 amino acids) and the lipid tail (3-HDA or 3-hydroxyoctanoic acid [3-HOA]). The peptide part of the CLPs in this group contains several unusual amino acids, including 2,3dihydro-2-aminobutyric acid (Dhb) and homoserine (Hse), the first always being in front of the allo-Thr residue (Table 1). The cyclic part of the peptide moiety contains five to eight amino acids and the lactone ring is formed between the C-terminal amino acid and the allo-Thr residue. Several tolaasinlike CLPs are produced by plant-pathogenic strains of Pseudomonas and constitute important virulence factors.

In terms of shear numbers of amino acids in the peptide moiety, CLPs in the syringomycin group are structurally similar to the CLPs in the viscosin group (Table 1). However, syringomycin-like CLPs harbor unusual amino acids, including Dhb, 2,4-diamino butyric acid (Dab), and the C-terminal 4chlorothreonine ( $\mathrm{Thr}[4-\mathrm{Cl}])$, the latter being important for the antifungal activity of syringomycin (Grgurina et al. 1994). Furthermore, the lactone ring is formed between the N-terminal Ser

Table 1. Simplified primary structures of cyclic lipopeptides (CLPs) produced by plant-associated Pseudomonas spp. ${ }^{\mathrm{a}}$

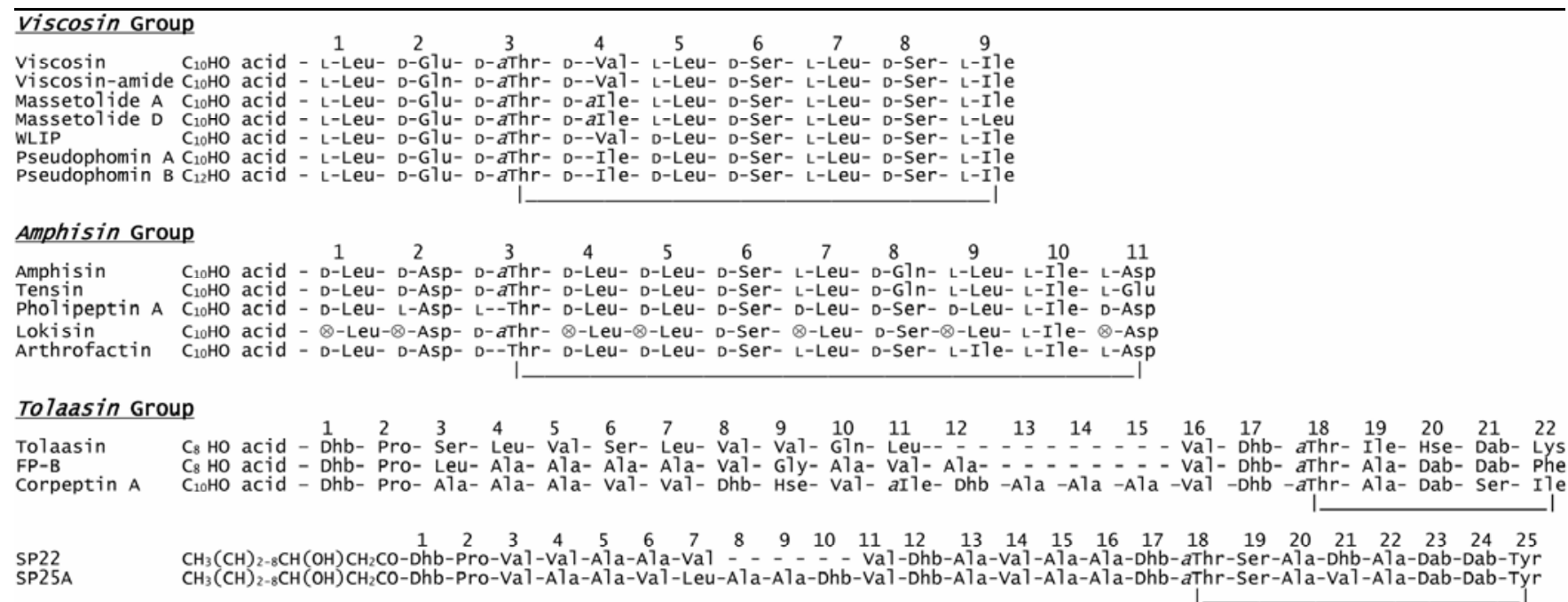

\section{syringomycin Group}

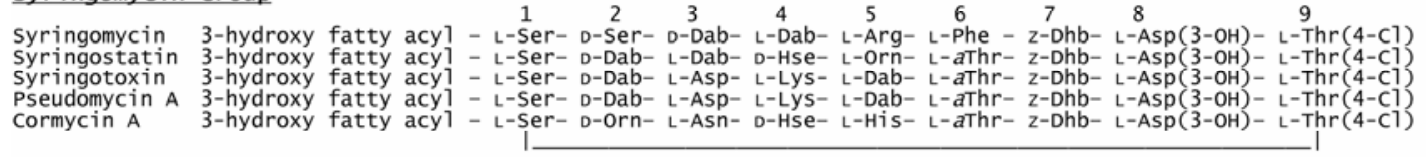

other

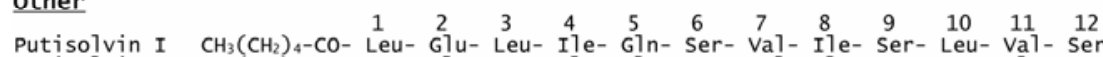

Putisolvin II $\mathrm{CH}_{3}\left(\mathrm{CH}_{2}\right)_{4}$-CO- Leu- Glu- Leu- Ile- Gln- Ser- val- Ile- Ser- Leu- xle- Ser

PFL2145/46/47 C22HO acid - Leu- Gix- $\begin{aligned} & 2 \\ & \text { aThr- }\end{aligned}$

\footnotetext{
a Adapted from Ballio et al. 1991; Ballio et al. 1995; Coiro et al. 1998; Gerard et al. 1997; Kuiper et al. 2004; Morikawa et al. 2000; Nybroe and Sørensen, 2004; Paulsen et al. 2006; Quail et al. 2002; and Scaloni et al. 2004. The lines represent the lactone ring of the cyclic lipopeptide. $\otimes$ : isomer not identified; Asp(3-OH): 3-hydroxyaspartic acid; Dab: 2,4-diaminobutyric acid; Dhb, 2,3-dihydroxy-2-aminobutyric acid; Glx: glutamic acid or glutamine; Hse: homoserine; alle: allo-isoleucine; Orn: ornithine; $\mathrm{Thr}(4-\mathrm{Cl})$ : 4-chlorothreonine; $a \mathrm{Thr}$ : allo-threonine; Xle: isoleucine or leucine; PFL2145/46/47 refers to the predicted lipodecapeptide of P. fluorescens strain Pf-5.
} 
and the C-terminal $\operatorname{Thr}(4-\mathrm{Cl})$; whereas, for members of the viscosin group, the ring usually is formed between the C-terminal amino acid and the D-allo-Thr at the third amino acid position in the peptide chain (Table 1). The fatty acid tail of CLPs in the syringomycin group may consist of a 3-hydroxy or 3,4-dihydroxy fatty acid composed of 10 to 14 carbon atoms. For example, three forms of syringomycin have been described which differ only in the length of the fatty acid moiety, being either decanoic, dodecanoic, or tetradecanoic acid (Bender et al. 1999; Bender and Scholz-Schroeder 2004).

The structures of a number of other CLPs from Pseudomonas spp. have been elucidated in the past years. These include arthrofactin produced by Pseudomonas sp. strain MIS38 (Morikawa et al. 1993; Roongsawang et al. 2003) and putisolvin I and II produced by P. putida PCL1445 (Kuiper et al. 2004). Arthrofactin contains an 11-amino acid peptide moiety linked to a $\beta$-hydroxydecanoyl tail. Based on its chemical structure, arthrofactin falls within the amphisin group and is most similar to lokisin (Table 1). Putisolvin I and II harbor some unique features, including a peptide moiety of 12 amino acids and a hexanoic lipid tail. The cyclization in the two putisolvins also is different from other CLPs because the linkage occurs between the C-terminal carboxyl group and the ninth amino acid residue (serine) instead of the first or third amino acid as described previously for many of the other CLPs (Table 1 ). Recently, in silico analysis of the whole genome sequence of the biocontrol strain P. fluorescens Pf-5 has resulted in the identification of a gene cluster that most likely encodes a cyclic lipodecapeptide (Paulsen et al. 2005). Although the amino acid composition of the peptide moiety of the predicted CLP of strain Pf-5 (Table 1) as well as the identity of the fatty acid tail needs to be confirmed by chemical analyses, this approach elegantly illustrates that knowledge of whole genome sequences allows the discovery of yet-unknown genes and traits which may be biologically relevant for the activity of antagonistic Pseudomonas spp.

\section{Activity.}

Given the structural diversity of CLPs produced by Pseudomonas spp. and other bacterial genera, Ron and Rosenberg (2001) postulated that CLPs and, more generally, microbial surface-active compounds (biosurfactants) also have different natural roles, some of which may be unique to the physiology and ecology of the producing microorganism. Several natural roles for CLPs and other biosurfactants were proposed (Ron and Rosenberg 2001), including their function in i) pathogenicity, ii) antimicrobial activity, iii) regulation of attachment and detachment to and from surfaces, and iv) motility. Another natural role, possibly limited to spore-forming bacteria, is that CLPs may function as signal molecules for coordinated growth and differentiation (Marahiel et al. 1997). To date, most of the hypotheses for the natural roles of CLPs and other biosurfactants have been derived mainly from their physical and chemical properties. In recent years, mutants deficient in CLP production have been obtained for several Pseudomonas strains and currently are being used to further investigate the natural roles of CLPs. In this section, several of the potential functions of CLPs produced by plant-associated Pseudomonas spp. will be discussed. Whenever possible, details on structure-function relationships will be included.

Role in plant pathogenesis. CLPs produced by plant-pathogenic $P$. syringae and $P$. fluorescens function as virulence factors and, as such, are not solely required for pathogenicity (Bender et al. 1999). For example, the production of syringomycin and syringopeptin by $P$. syringae pv. syringae substantially increases disease severity, although disease may still occur in their absence (Scholz-Schroeder et al. 2001a). Similarly, a viscosin-deficient mutant of a pectolytic strain of $P$. fluorescens still caused decay of wounded broccoli florets, but the decay failed to spread to adjacent nonwounded florets (Hildebrand et al. 1998). One of the main modes of action of CLPs produced by plant-pathogenic Pseudomonas spp., including syringomycin, syringopeptin, and tolaasin, involves the formation of ion channels in the host plasma membrane leading to cytolysis (Dalla Serra et al. 1999; Hutchison and Gross 1997; Hutchison et al. 1995; Mott and Takemoto 1989; Rainey et al. 1991). Pore formation results in the alkalization of the intercellular fluid and in the release of multiple cellular compounds, conditions that are favorable for further multiplication and increased CLP production by the invading bacteria. At high concentrations (well above the critical micelle concentration [CMC value]), CLPs can directly solubilize plasma membranes. In several studies (Bender et al. 1999), solubilization of membranes also was demonstrated for erythrocytes. Interestingly, erythrocyte hemolysis by tolaasin can be inhibited by addition of divalent metal ions such as $\mathrm{Zn}^{2+}, \mathrm{Ca}^{2+}$, and $\mathrm{Mg}^{2+}$ (Rainey et al. 1991). Given that pre-incubation of tolaasin with $\mathrm{Zn}^{2+}$ did not affect its ability to lyse erythrocytes and that cells pretreated with $\mathrm{Zn}^{2+}$ were no less susceptible to tolaasininduced lysis than untreated cells, Rainey and associates (1991) proposed that the inhibitory effect of divalent metal ions operates by binding to negatively charged groups on the extracellular side of the plasma membrane close to the site of pore formation. Recent studies with surfactin (Dufour et al. 2005) further indicated that the cyclic character of the peptide moiety is important for erythrocyte hemolysis because linear products of surfactin failed to cause lysis.

In addition to the direct toxic effects of CLPs from pathogenic Pseudomonas spp. on plant cells, their surfactant properties play an important indirect role in virulence by facilitating colonization of plant tissue and enhancing physical access of cell-wall-degrading enzymes (CWDE) to the plant surface (Hildebrand et al. 1998; Hutchison and Johnstone 1993; Lindow and Brandl 2003). Although the order in which CLPs and CWDE operate is subject to discussion (Fogliano et al. 2002), studies on the indirect and direct effects of CLPs on plant cells, including their impact on physiological processes and signaling pathways (Bender et al. 1999), clearly exemplify the versatile functions of CLPs in pathogenicity. From a more applied perspective, knowledge of the detrimental effects of CLPs on plant cells has led to an increased interest in the potential use of these CLPs or the producing Pseudomonas spp. as microbial herbicides (Li et al. 2003; Pedras et al. 2003).

Antimicrobial activity. CLPs produced by Pseudomonas and Bacillus spp. also have received considerable attention for their activity against a range of other microorganisms, including viruses, mycoplasmas, trypanosomes, bacteria, fungi, and oomycetes. Studies on the antiviral activity of CLPs produced by Pseudomonas spp. date back to work by Groupé and colleagues in 1951 (Nybroe and Sørensen 2004), in which viscosin was shown to have activity against enveloped human-pathogenic viruses, including the infectious bronchitis virus. Similarly, surfactin was shown to inactivate multiple enveloped viruses, including herpes viruses and retroviruses (Vollenbroich et al. 1997a). Electron microscopy indicated that surfactin acts directly on the lipid envelope, leading to disintegration of the virus particles (Vollenbroich et al. 1997a). Additional studies revealed that surfactins with fatty acid chains of 13 carbon atoms showed low antiviral activity compared with $\mathrm{C} 14$ and C15 isoforms, indicating that the hydrophobicity is an important determinant of the antiviral activity of surfactin (Kracht et al. 1999). Disintegration of membranes also was shown to be the primary activity of surfactin against several mycoplasmas (Vollenbroich et al. 1997b). Surfactin was active only at concentrations above 
the CMC value, suggesting that disruption of mycoplasma membranes is due to nonspecific detergent activity.

In studies on the human pathogen Trypanosoma cruzi, the causal agent of Chagas's disease, Mercado and Colon-Whitt (1982) observed lysis of trypomastigotes isolated from the blood of infected mice. Further analysis of the parasite samples led to the isolation of a $P$. fluorescens isolate that produces viscosin, which itself also causes trypanosomal lysis (Burke et al. 1999). An interesting microscopic observation was that, in direct interactions, the $P$. fluorescens isolate approached a single flagellate of $T$. cruzi at the posterior end, the site of the flagellar origin, resulting in immobilization (Mercado and Colonwhitt 1982). Observations further revealed rounding up of the parasite with the flagellum coiled around the cell body, followed by disintegration. Similar stages were observed in the disintegration process of zoospores of oomycete pathogens exposed to massetolide A and viscosin produced by antagonistic strains of $P$. fluorescens (De Souza et al. 2003; J. M. Raaijmakers, personal communication).

Studies on the antibacterial activity of CLPs have focused primarily on human-pathogenic bacteria and, in particular, the gram positives. In summary, activity was shown for corpeptins, syringopeptins, and tolaasin against Bacillus megaterium (Emanuele et al. 1998; Lavermicocca et al. 1997; Soler-Rivas et al. 1999), and for massetolides, viscosin, syringopeptin, and syringomycins against Mycobacterium tuberculosis, $M$. aviumintercellulare, and M. smegmalis (Buber et al. 2002; El Sayed et al. 2000; Gerard et al. 1997). A twofold difference between the activity of massetolide A and viscosin against $M$. tuberculosis and M. avium-intercellulare (Gerard et al. 1997) illustrated that a difference of only 1 amino acid residue in the peptide moiety (Table 1) may have a significant impact on the antibacterial activity. For massetolide A and viscosin, no activity was observed against a panel of other human-pathogenic bacteria, including Escherichia coli and Staphylococcus aureus (Gerard et al. 1997). Also, for putisolvin produced by $P$. putida PCL1445, no antibacterial effects against $P$. fluorescens and $P$. aeruginosa were observed when these strains were grown together on agar plates (Kuiper et al. 2004). The apparent lack of activity of several CLPs against gram-negative bacteria has been ascribed to protective effects of the outer membrane (Nybroe and Sørensen 2004). However, recent studies by Bais and associates (2004) indicate that this general observation does not apply to all CLPs; in their study, surfactin was shown to have bactericidal activity against $P$. syringae pv. tomato.

The antifungal activity has been studied for many different CLPs and for a wide variety of plant- and human-pathogenic fungi and yeasts, including Rhizoctonia solani, Phoma lingam, Alternaria brassicae, Sclerotinia sclerotiorum, Geotrichum candidum, Botrytis cinerea, Ophiostoma ulmi, Aspergillus and Fusarium spp., Penicillium digitatum, Cryptococcus neoformans, Candida albicans, and C. glabrans (Nybroe and Sørensen 2004). In particular, the studies with viscosinamide produced by antagonistic Pseudomonas sp. strain DR54 provide several lines of evidence that CLPs are important constituents in the biological control of plant-pathogenic fungi. In vitro studies showed that viscosinamide adversely affected mycelium of $R$. solani and the oomycete Pythium ultimum, causing reduced growth and intracellular activity, hyphal swellings, increased branching, and rosette formation (Hansen et al. 2000; Thrane et al. 1999, 2000a). Viscosinamide is produced by strain DR54 in situ (Nielsen and Sorensen 2003), and several of the adverse effects on $R$. solani and $P$. ultimum recorded in vitro, including reduced mycelium density and intracellular activity of $P$. ultimum and reduced sclerotia formation by $R$. solani, also were observed in situ (Thrane et al. 1999, 2000b, 2001). However, in these and several other studies with antagonistic CLP-producing Pseudomonas strains, a comparison between the biocontrol activity of a wild type strain and CLP-deficient mutants was not included. Advances in the understanding of CLP biosynthesis have resulted in the construction of CLP-deficient mutants and also mutants overproducing CLPs. For example, a mutant of Bacillus subtilis 6051 defective in surfactin production was substantially less effective than the wild-type strain in controlling root infection of Arabidopsis by Pseudomonas syringae (Bais et al. 2004). Furthermore, a derivative of $B$. subtilis BBG100 that overproduces mycosubtilin showed an increased activity against Pythium spp. on tomato seedlings (Leclère et al. 2005). Studies with Pseudomonas fluorescens R1SS101 also showed reduced activity of massetolide A-deficient mutants against several plant-pathogenic fungi and oomycetes (A. Ficke and J. M. Raaijmakers, personal communications). The activity of massetolide A produced by strain R1SS101 against Pythium spp. has, so far, been attributed mainly to their zoosporicidal activity (De Souza et al. 2003). The zoosporicidal activity of massetolide A also may explain, at least in part, the biocontrol activity of strain R1SS101 against a range of other oomycete pathogens, including Phytophthora spp. However, the observation that strain R1SS101 and purified massetolide $\mathrm{A}$ also exert significant biocontrol activity against Pythium spp. that do not produce zoospores point to other modes of action (J. M. Raaijmakers, personal communications). A complicating factor in studying the role of CLPs in interactions between antagonistic Pseudomonas strains and plant pathogens is that CLPs have a dual function, as described previously for their role in pathogenesis. In addition to their direct effects on pathogen membranes, their surface activity also may enhance or even be essential for the delivery of and exposure of target pathogens to other antagonistic traits. In this context, Fogliano and associates (2002) demonstrated that, in combination, with CWDE of Trichoderma atroviride, CLPs produced by Pseudomonas syringae acted synergistically in antagonism toward several plant-pathogenic fungi.

Attachment and detachment. Attachment and detachment of bacteria to synthetic and natural surfaces has been the subject of numerous studies in the past and present, especially because of the importance of these processes in biofilm formation (Neu 1996; O'Toole et al. 2000). The role of CLPs in attachment or biofilm formation has been studied for several bacterial genera, including Pseudomonas and Bacillus spp. Arthrofactin produced by Pseudomonas MIS38 was shown to play an important role in developing mature biofilms (Roongsawang et al. 2003). An arthrofactin-deficient mutant formed unstable, but more, biofilms than the wild-type strain; furthermore, the structure of the biofilm was different, being more flat and fused for the mutant in contrast to the well-developed biofilms separated by channels for the wild-type strain. For $P$. putida PCL1445, Kuiper and associates (2004) showed that putisolvins I and II also influenced biofilm formation. The biofilm formed by a putisolvin-deficient mutant was strongly increased, containing more cells which formed aggregates that were not distributed as regularly as those of the parental strain. Addition of purified putisolvin I to the growth medium prior to incubation reduced biofilm formation by the wild-type strain in a concentration-dependent manner. Furthermore, putisolvins I and II also adversely affected biofilm formation of at least two other Pseudomonas strains and were shown to break down existing biofilms (Kuiper et al. 2004). In addition, surfactin inhibits biofilm formation of several human-pathogenic bacteria, including Salmonella spp. (Mireles et al. 2001). This capacity to destroy existing biofilms emphasizes the potential use of these CLPs in removal of biofilms formed by hazardous bacteria. Furthermore, surfactin was shown to play an essential role in adherence of $B$. subtilis 6051 to a synthetic surface and in biofilm formation on Arabidopsis roots (Bais et al. 2004). 
They postulated that biofilm formation and CLP production may enable bacteria to efficiently colonize plant roots, thereby providing protection to their host. Recent studies by Nielsen and associates (2005) showed that the production of amphisin is an important trait for Pseudomonas sp. strain DSS73 to colonize sugar beet seed and barley straw residues. However, given that CLP production impairs biofilm formation for several Pseudomonas strains (discussed above), Nielsen and associates (2005) questioned the role of amphisin in biofilm formation during colonization of seed and straw by strain DSS73. Instead, they postulated that amphisin contributes to cell proliferation of strain DSS73 on the germinating seed and supports motility toward the plant material. Other putative roles of CLPs in colonization and proliferation suggested by Nielsen and associates (2005) included relieve of a nutrient limitation or a toxic effect of unknown seed components.

Motility. As described previously, CLPs facilitate the movement of plant-pathogenic Pseudomonas spp. on the phylloplane (Hildebrand et al. 1998; Lindow and Brandl 2003). Also, for antagonistic Pseudomonas strains, efficient colonization of the phytosphere (spermosphere, rhizosphere, and phyllosphere) as well as in situ production and delivery of the antagonistic traits at the right time and place are key aspects of their success to control plant pathogens (Lugtenberg et al. 2001; Whipps 2001). Several studies have shown that CLPs produced by antagonistic Pseudomonas strains and other bacterial genera are essential for surface motility (Andersen et al. 2003; Kuiper et al. 2004; Lindum et al. 1998; Nielsen et al. 2002; Roongsawang et al. 2003). For Pseudomonas sp. strain DSS73, amphisin production plays an important role in surface motility and in efficient containment of mycelial growth of root-infecting fungi, which most likely results from a combination of spatial limitation and delivery of antifungal compounds (Andersen et al. 2003). The reduced surface motility of amphisin-deficient mutants could be restored by addition of amphisin to the medium and also by addition of other CLPs, including tensin, viscosi- namide, and serrawettin. Interestingly, several synthetic surfactants failed to complement the deficiency in surface motility of the mutants, suggesting that not only the reduction of surface tension is essential in motility but also the physical-chemical nature of the surfactant (Andersen et al. 2003).

\section{Biosynthesis.}

CLPs are produced nonribosomally on large, multifunctional peptide synthetases via a thiotemplate process. Nonribosomal peptide synthesis has been the subject of numerous biochemical and molecular studies. For a more detailed understanding of the structural and functional characteristics of the enzymes involved, we refer to several reviews (Challis and Naismith 2004; Challis et al. 2000; Finking and Marahiel 2004; Marahiel et al. 1997; Stachelhaus et al. 1999; von Dohren et al. 1999). As elegantly described by Gewolb (2002), nonribosomal peptide synthetases (NRPSs) are not bound by the restrictions of the "ribosome's rulebooks" and are involved not only in CLP production but also in the synthesis of an array of other unusual and potent peptides, including several clinically important drugs such as penicillin, vancomycin, and cyclosporin. NRPSs possess a modular structure and each module is a building block resulting in the stepwise incorporation and modification of one amino acid unit. Their substrates are not restricted to the usual proteinogenic amino acids but also can incorporate multiple nonproteinogenic D-amino acids, carboxy acids, or fatty acids (Gewolb 2002; Sieber and Marahiel 2005). The order and number of the modules of an NRPS protein are, in many cases, colinear to the amino acid sequence of the corresponding peptide moiety of the final CLP molecule ("colinearity rule"). A typical NRPS module consists of an adenylation (A) domain responsible for amino acid activation, a thiolation (T or, alternatively, PCP) domain for thioesterification of the activated amino acid, and a condensation (C) domain for peptide bond formation between two neighboring substrates to elongate the peptide chain (Fig. 1). These catalytic domains generate a linear
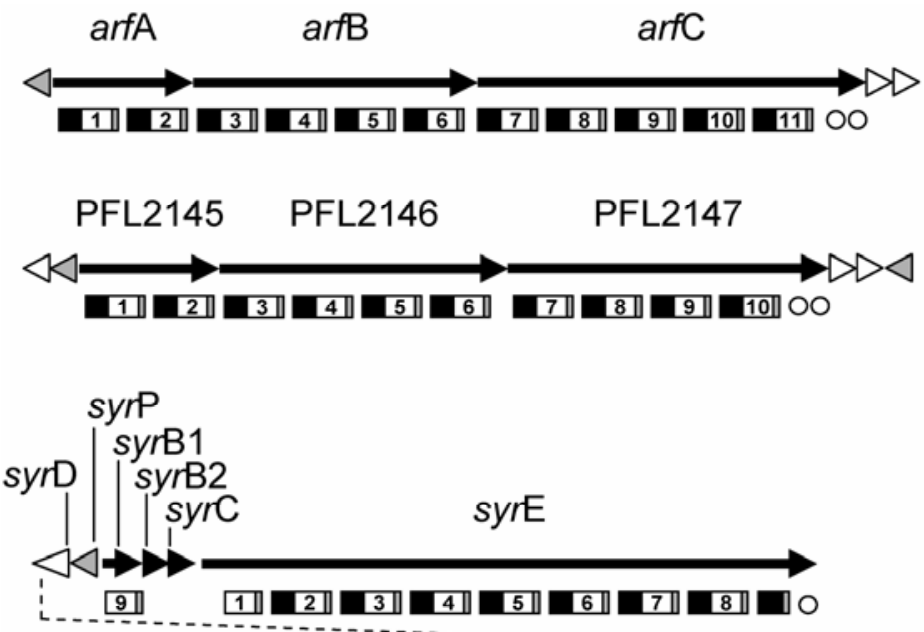

11 One NRPS module

- Condensation domain

Adenylation domain

\. Thiolation domain

○ Thioesterase domain

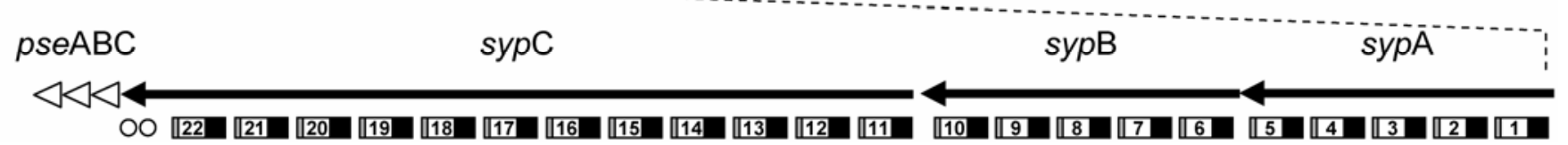

Fig. 1. Physical maps of the synthetic templates for arthrofactin (arfABC) of Pseudomonas sp. strain MIS38 (Roongsawang et al. 2003), the predicted lipodecapeptide (PFL2145/46/47) of P. fluorescens strain Pf-5 (Paulsen et al. 2005), and syringomycin (syr) and syringopeptin (syp) of $P$. syringae pv. syringae strain B301D (Bender and Scholz-Schroeder 2004). In the genome of P. syringae pv. syringae, the syringomycin and syringopeptin gene clusters are physically linked (indicated by a dotted line). The modular structure is depicted under each nonribosomal peptide synthetase (NRPS) gene. The number in each module indicates the position of the incorporated amino acid in the peptide moiety of the cyclic lipopeptide (CLP). Condensation (C) domains are responsible for peptide bond formation between neighboring amino acids. Adenylation (A) domains activate each of the respective amino acids and thiolation (T) domains are responsible for thioesterification. The thioesterase (TE) domains at the end of the synthetic templates are involved in cyclization of the CLP molecule. White arrows represent putative transporter genes and grey arrows indicate putative regulatory genes. 
peptide which is cleaved at the end of the assembly line by a thioesterase (TE) domain, which results in the release of a linear product or a cyclic compound via an intramolecular cyclization reaction. In the latter case, TE domains also have been referred to as peptide cyclases (Sieber and Marahiel 2005). These cyclases display a high level of specificity by selecting a particular residue of the substrate for cyclization, which possibly explains the structural diversity in the peptide ring sizes described previously for the various CLP-groups of plantassociated Pseudomonas spp. (Table 1). Additional domains in nonribosomal peptide synthesis may include an epimerization (E) domain, responsible for the conversion of the L- or D-configuration of an amino acid. For example, in modules 3 and 6 of the surfactin synthetic template in Bacillus spp., there are two internal E domains that result in the incorporation of a DLeu at the corresponding positions in the peptide moiety (Peypoux et al. 1999; Sieber and Marahiel 2005).

For CLP-producing Pseudomonas spp., a number of partial and complete sequences of NRPSs have been obtained over the past decade (Table 2). Two of the best-characterized bio- synthetic templates are the synthetase clusters for arthrofactin (Roongsawang et al. 2003) and syringomycin (Bender et al. 1999; Guenzi et al. 1998a). Arthrofactin synthesis is governed by three NRPSs genes, designated $\operatorname{arfA}$, arfB, and $\operatorname{arfC}$ (Fig. 1). Based on analogy with other NRPSs, ArfA, B, and C are composed of a total of 11 modules, which is consistent with the number of amino acids in the peptide moiety (Fig. 1; Table 1). Each module contains the typical features of NRPSs, including the $\mathrm{A}, \mathrm{C}$, and $\mathrm{T}$ domains. In this respect, the arthrofactin synthetase cluster is a classic example of the colinearity rule. Although seven of the 11 amino acids in the peptide moiety of arthrofactin have the D-configuration (Table 1), none of the 11 modules in the arf synthetic cluster harbor an internal $\mathrm{E}$ domain for the conversion from L to D form. Also, in the synthetic templates of syringopeptin (Scholz-Schroeder et al. 2003), the predicted lipodecapeptide of strain Pf-5 (Paulsen et al. 2005), and in the gene clusters for massetolide A and viscosin production by antagonistic P. fluorescens strains (M. J. D. de Kock and J. M. Raaijmakers, personal communications), internal $\mathrm{E}$ domains were not found. Based on additional ATP-

Table 2. Genes involved in the biosynthesis and regulation of cyclic lipopeptides (CLPs) produced by plant-associated Pseudomonas spp. ${ }^{\text {a }}$

\begin{tabular}{|c|c|c|c|c|c|c|}
\hline CLP group & CLP & Species/strain & Gene/protein information & GenBank accession no. & $\mathbf{P} / \mathbf{C}^{*}$ & References \\
\hline \multicolumn{7}{|c|}{ Synthesis (including efflux transporters) } \\
\hline \multirow[t]{2}{*}{ Viscosin } & Viscosin & P. fluorescens PfA7B & $\begin{array}{l}\text { Nonribosomal peptide } \\
\text { synthetases }\end{array}$ & No sequence available & - & Braun et al. 2001 \\
\hline & Massetolide A & P. fluorescens R1SS101 & $\begin{array}{l}\text { Nonribosomal peptide } \\
\text { synthetases }\end{array}$ & AY303770; AY303771 & $\mathrm{P}$ & De Souza et al. 2003 \\
\hline \multirow[t]{4}{*}{ Amphisin } & Amphisin & $\begin{array}{l}\text { Pseudomonas sp. strain } \\
\text { DSS73 }\end{array}$ & ams $Y$, peptide synthetase & AJ416154 & $\mathrm{P}$ & Koch et al. 2002 \\
\hline & Arthrofactin & Pseudomonas sp. MIS38 & $\begin{array}{l}\operatorname{arfA} ; \operatorname{arfB} ; \operatorname{arfC} ; \\
\text { nonribosomal peptide } \\
\text { synthetases }\end{array}$ & AB 107223 & $\mathrm{C}$ & $\begin{array}{l}\text { Roongsawang et al. } \\
2003\end{array}$ \\
\hline & Arthrofactin & Pseudomonas sp. MIS38 & $\begin{array}{l}\text { ORF5; putative outer } \\
\text { membrane efflux protein }\end{array}$ & AB 107223 & $\mathrm{C}$ & $\begin{array}{l}\text { Roongsawang et al. } \\
2003\end{array}$ \\
\hline & Arthrofactin & Pseudomonas sp. MIS38 & $\begin{array}{l}\text { ORF6; putative ABC } \\
\text { transporter protein }\end{array}$ & AB 107223 & $\mathrm{P}$ & $\begin{array}{l}\text { Roongsawang et al. } \\
2003\end{array}$ \\
\hline \multirow[t]{5}{*}{ Tolaasin } & Tolaasin & P. tolaasii & $\begin{array}{l}\text { TL1, TL2, TL3; high- } \\
\text { molecular weight protein }\end{array}$ & No sequence available & - & Rainey et al. 1993 \\
\hline & Tolaasin & Pseudomonas NZ17 & $\begin{array}{l}\text { Homology to syringomycin } \\
\text { synthetase }\end{array}$ & No sequence available & - & Godfrey et al. 2001 \\
\hline & Syringopeptin & $\begin{array}{l}\text { P. syringae pv. syringae } \\
\text { B728a }\end{array}$ & $\begin{array}{l}\text { Syringopeptin synthetase } \\
\text { genes }\end{array}$ & CP000075 & $\mathrm{C}$ & Feil et al. 2005 \\
\hline & Syringopeptin & $\begin{array}{l}\text { P. syringae pv. syringae } \\
\text { B301D }\end{array}$ & $\begin{array}{l}\text { sypA, syp } B, \text { sypC } \\
\text { syringopeptin synthetase }\end{array}$ & AF286216 & $\mathrm{C}$ & $\begin{array}{l}\text { Scholz-Schroeder et al. } \\
\text { 2001a,b, } 2003\end{array}$ \\
\hline & Syringopeptin & $\begin{array}{l}\text { P. syringae pv. syringae } \\
\text { B301D }\end{array}$ & $\begin{array}{l}\text { pseABC; tripartite } \\
\text { resistance-nodulation-cell } \\
\text { division transporter } \\
\text { system }\end{array}$ & No sequence available & - & Kang and Gross 2005 \\
\hline \multirow[t]{7}{*}{ Syringomycin } & Syringomycin & $\begin{array}{l}P . \text { syringae pv. syringae } \\
\text { B728a }\end{array}$ & $\begin{array}{l}\text { Syrinogmycin synthetase } \\
\text { genes }\end{array}$ & CP000075 & $\mathrm{C}$ & Feil et al. 2005 \\
\hline & Syringomycin & $\begin{array}{l}\text { P. syringae pv. syringae } \\
\text { B301D }\end{array}$ & $\begin{array}{l}\text { syrE; nonribosomal peptide } \\
\text { synthetase }\end{array}$ & AF047828 & $\mathrm{C}$ & $\begin{array}{l}\text { Guenzi et al. 1998; } \\
\text { Scholz-Schroeder et } \\
\text { al. 2001a }\end{array}$ \\
\hline & Syringomycin & $\begin{array}{l}\text { P. syringae pv. syringae } \\
\text { B301D }\end{array}$ & $\begin{array}{l}\text { syr } B 1 \text {; nonribosomal } \\
\text { peptide synthetase }\end{array}$ & $\mathrm{U} 25130$ & $\mathrm{C}$ & $\begin{array}{l}\text { Zhang et al. 1995; } \\
\text { Guenzi et al. } 1998\end{array}$ \\
\hline & Syringomycin & $\begin{array}{l}\text { P. syringae pv. syringae } \\
\text { B301D }\end{array}$ & syrC; thioesterase & U25130 & $\mathrm{C}$ & $\begin{array}{l}\text { Zhang et al. 1995; } \\
\text { Guenzi et al. } 1998\end{array}$ \\
\hline & Syringomycin & $\begin{array}{l}\text { P. syringae pv. syringae } \\
\text { B301D }\end{array}$ & $\begin{array}{l}\text { syrB2; nonheme } \mathrm{Fe}^{\mathrm{II}} \\
\text { halogenase }\end{array}$ & $\mathrm{U} 25130$ & $\mathrm{C}$ & Vaillancourt et al. 2005 \\
\hline & Syringomycin & $\begin{array}{l}\text { P. syringae pv. syringae } \\
\text { B301D }\end{array}$ & $\begin{array}{l}\text { syrD; putative } \mathrm{ABC} \\
\text { transporter protein }\end{array}$ & M97223 & $\mathrm{C}$ & Quigley et al. 1993 \\
\hline & Syringomycin & $\begin{array}{l}\text { P. syringae pv. syringae } \\
\text { B } 301 \mathrm{D}\end{array}$ & $\begin{array}{l}\text { pseABC; tripartite } \\
\text { resistance-nodulation-cell } \\
\text { division transporter } \\
\text { system }\end{array}$ & No sequence available & - & Kang and Gross 2005 \\
\hline \multirow[t]{3}{*}{ Other } & Putisolvin & P. putida PCL1445 & psoA; putisolvin synthetase & DQ151887 & $\mathrm{P}$ & $\begin{array}{l}\text { Kuiper et al. 2004; } \\
\text { Dubern et al. } 2005\end{array}$ \\
\hline & Viscosin-like & P. fluorescens Pf-5 & $\begin{array}{l}\text { Nonribosomal peptide } \\
\text { synthetases }\end{array}$ & $\begin{array}{l}\text { CP000076 (PFL2145; } \\
\text { PFL2146; PFL2147) }\end{array}$ & $\mathrm{C}$ & Paulsen et al. 2005 \\
\hline & & & & & \multicolumn{2}{|c|}{ Continued on following page } \\
\hline
\end{tabular}

${ }^{\mathrm{a}} \mathrm{C}=$ complete $\mathrm{CDS}$ and $\mathrm{P}=$ partial sequence. 
PPi exchange assays with a total of 20 typical L amino acids, Roongsawang and associates (2003) showed that the D-Leu1 A domain of the arthrofactin synthetic template adopted only LLeu as a substrate and not D-Leu, suggesting that an external racemase is responsible for the $\mathrm{L}$ to $\mathrm{D}$ conversion. This suggestion for an external racemase was further supported by specific sequence motifs in the $\mathrm{T}$ domains of the arf synthetic template. $\mathrm{T}$ domains that are associated with an internal $\mathrm{E}$ domain, as in the surfactin synthetic template in Bacillus spp., have the highly conserved motif (F[F/Y]XXGGDSIKA[I/ L]Q), in which the aspartate residue in front of the serine residue is important in the interaction between the $\mathrm{T}$ and internal E domains (Linne et al. 2001). In the arthrofactin synthetic template, the $\mathrm{T}$ domains contain a different conserved sequence motif (FFELGGHSLLA[V/M]) and can be further classified into the $\mathrm{T}(\mathrm{L})$ and $\mathrm{T}(\mathrm{D})$ domains, responsible for transferring $\mathrm{L}$ or $\mathrm{D}$ amino acids, respectively, to the intermediate peptide moiety (Roongsawang et al. 2003). Roongsawang and associates (2003) suggested that these differences may reflect the different topologies between A and T domains or, alternatively, be important for the recognition by an external racemase that is necessary for D-amino acid incorporation.

The C-terminal regions of CLP synthetic templates in Pseudomonas spp., including SypC in P. syringae and PFL2147 of $P$. fluorescens Pf-5, usually harbor one or two TE domains (Fig. 1). Also, in the arthrofactin synthetic template, the C-ter- minal region of ArfC contains two putative TE domains designated ArfCTe1 and ArfCTe2 (Fig. 1). Based on phylogenetic analyses and alignments of the amino acid sequences, it was postulated that ArfCTe1 and ArfCTe 2 have a separate or, possibly, a coordinated function in hydrolysis and cyclization of the final product (Roongsawang et al. 2003). Further analysis of the regions downstream of $\operatorname{arfC}$ resulted in the identification of two other genes, designated ORF5 and ORF6 (Roongsawang et al. 2003) (Fig. 1). Based on the direction of transcription of these two open reading frames (ORFs) and their homology to ATP-dependent transport proteins, these two ORFs were postulated to play a role in the secretion of arthrofactin (Roongsawang et al. 2003). The physical link between CLP synthetic templates and putative efflux genes also is the case for the predicted lipodecapeptide of $P$. fluorescens Pf-5 (Paulsen et al. 2005) (Fig. 1) and for syringopeptin and syringomycin of $P$. syringae pv. syringae (Feil et al. 2005; Scholz-Schroeder et al. 2001b) (Fig. 1).

In the plant pathogen $P$. syringae pv. syringae, the gene cluster for syringomycin synthesis makes up a substantial portion of the total genome. Together with the syringopeptin cluster, it composes a region of $132 \mathrm{~kb}$ which accounts for approximately $2 \%$ of the genome (Feil et al. 2005; Scholz-Schroeder et al. 2001b, 2003; Wang et al. in press; D. C. Gross, personal communication). This cluster, referred to as the syr-syp genomic island (Scholz-Schroeder et al. 2001b), was not found in the genome of $P$. syringae pv. tomato DC3000 (Feil et al. 2005).

Table 2. Continued from preceding page

\begin{tabular}{|c|c|c|c|c|c|c|}
\hline CLP group & CLP & Species/strain & Gene/protein information & GenBank accession no. & $\mathbf{P} / \mathbf{C}^{*}$ & References \\
\hline \multicolumn{7}{|l|}{ Regulation } \\
\hline Viscosin & Viscosin & P. fluorescens 5064 & AHL biosynthesis & No sequence available & - & Cui et al. 2005 \\
\hline \multirow[t]{2}{*}{ Amphisin } & Amphisin & $\begin{array}{l}\text { Pseudomonas sp. strain } \\
\text { DSS73 }\end{array}$ & $\begin{array}{l}\text { gacS; sensor kinase in two- } \\
\text { component regulatory } \\
\text { system }\end{array}$ & AJ416155 & $\mathrm{P}$ & Koch et al. 2002 \\
\hline & Arthrofactin & Pseudomonas sp. MIS38 & $\begin{array}{l}\text { ORF1; putative DNA } \\
\text { binding protein (luxR } \\
\text { type) }\end{array}$ & AB107223 & $\mathrm{C}$ & $\begin{array}{l}\text { Roongsawang et al. } \\
2003\end{array}$ \\
\hline \multirow[t]{3}{*}{ Tolaasin } & Tolaasin & P. tolaasii & $\begin{array}{l}\text { pheN; two-component } \\
\text { regulatory protein }(\mathrm{GacS})\end{array}$ & U95300 & $\mathrm{C}$ & Grewal et al. 1995 \\
\hline & Syringopeptin & $\begin{array}{l}\text { P. syringae pv. syringae } \\
\text { B728a }\end{array}$ & $\begin{array}{l}\text { gidA; initiation of } \\
\text { chromosome replication }\end{array}$ & AF302083 & $\mathrm{C}$ & $\begin{array}{l}\text { Kinscherf and Willis } \\
2002\end{array}$ \\
\hline & Syringopeptin & $\begin{array}{l}\text { P. syringae pv. syringae } \\
\text { B301D }\end{array}$ & $\begin{array}{l}\text { salA, } \operatorname{syr} G, \operatorname{syr} F ; \text { putative } \\
\text { DNA-binding regulatory } \\
\text { proteins (luxR type) }\end{array}$ & AF372703 & $\mathrm{C}$ & Lu et al. 2002 \\
\hline \multirow[t]{7}{*}{ Syringomycin } & Syringomycin & $\begin{array}{l}\text { P. syringae pv. syringae } \\
\text { B728a }\end{array}$ & $\begin{array}{l}\text { gidA; initiation of } \\
\text { chromosome replication }\end{array}$ & AF302083 & $\mathrm{C}$ & $\begin{array}{l}\text { Kinscherf and Willis } \\
2002\end{array}$ \\
\hline & Syringomycin & $\begin{array}{l}\text { P. syringae pv. syringae } \\
\text { B728a }\end{array}$ & $\begin{array}{l}\text { lemA; two-component } \\
\text { regulatory protein }(\mathrm{GacS})\end{array}$ & M80477 & $\mathrm{C}$ & $\begin{array}{l}\text { Hrabak and Willis } \\
\text { 1992; Kitten et } \\
\text { al.1998 }\end{array}$ \\
\hline & Syringomycin & $\begin{array}{l}\text { P. syringae pv. syringae } \\
\text { B728a }\end{array}$ & $\begin{array}{l}\text { gacA; response regulator in } \\
\text { two-component regulatory } \\
\text { system }\end{array}$ & CP000075 & $\mathrm{C}$ & $\begin{array}{l}\text { Rich et al. 1994; Feil et } \\
\text { al. } 2005\end{array}$ \\
\hline & Syringomycin & $\begin{array}{l}\text { P. syringae pv. syringae } \\
\text { B728a }\end{array}$ & $\begin{array}{l}\text { salA; putative DNA-binding } \\
\text { protein (luxR type) }\end{array}$ & AF022808 & $\mathrm{C}$ & Kitten et al. 1998 \\
\hline & Syringomycin & $\begin{array}{l}\text { P. syringae pv. syringae } \\
\text { B301D }\end{array}$ & $\begin{array}{l}\text { salA, syrG, syrF; putative } \\
\text { DNA-binding proteins } \\
\text { (luxR type) }\end{array}$ & AF372703 & $\mathrm{C}$ & Lu et al. 2002 \\
\hline & Syringomycin & $\begin{array}{l}\text { P. syringae pv. syringae } \\
\text { B301D }\end{array}$ & $\begin{array}{l}\text { syrA; } N \text {-acetylglutamate } \\
\text { synthase (arginine } \\
\text { biosynthesis) }\end{array}$ & AY374326 & $\mathrm{C}$ & Lu et al. 2003 \\
\hline & Syringomycin & $\begin{array}{l}\text { P. syringae pv. syringae } \\
\text { B301D }\end{array}$ & $\begin{array}{l}\text { syrP; histidine kinase in } \\
\text { two-component regulatory } \\
\text { system (phosphorelay) }\end{array}$ & U88574 & $\mathrm{C}$ & Zhang et al. 1997 \\
\hline \multirow[t]{3}{*}{ Other } & Putisolvin & P. putida PCL1445 & $\begin{array}{l}\text { gacA; response regulator in } \\
\text { two-component regulatory } \\
\text { system }\end{array}$ & No sequence available & - & Dubern et al. 2005 \\
\hline & Putisolvin & P. putida PCL1445 & $\begin{array}{l}\text { gac } S \text {; sensor kinase in two- } \\
\text { component regulatory } \\
\text { system }\end{array}$ & No sequence available & - & Dubern et al. 2005 \\
\hline & Putisolvin & P. putida PCL1445 & $\begin{array}{l}\text { dnaK; dnaJ, grpE; heat- } \\
\text { shock proteins }\end{array}$ & AY823737 & $\mathrm{C}$ & Dubern et al. 2005 \\
\hline
\end{tabular}


In contrast to the arthrofactin gene cluster discussed above, the syringomycin gene cluster has several different and unique features. First of all, the organization of the structural synthetase genes does not respect the colinearity rule because the syrB1 gene, responsible for the incorporation of the ninth amino acid in the peptide moiety, is located upstream of $s y r E$, which encodes the first eight amino acids (Fig. 1). Another interesting structural feature is the positioning of the single TE domain, which is not fused to the C-terminus of the last amino acid binding domain SyrB1 but, instead, to the C-terminus of SyrE$\mathrm{M} 8$, the module required for the incorporation of the eighth amino acid (Bender and Scholz-Schroeder 2004; Guenzi et al. 1998a). The C-terminus of syrE does contain elements of a ninth module, including condensation and thiolation domains, but lacks an adenylation domain which is proposed to be provided by SyrB1 (Bender et al. 1999; Bender and ScholzSchroeder 2004). Recent studies have further indicated that SyrB1 activates the amino acid L-Thr, after which SyrB2-mediated chlorination takes place to yield the biologically active ninth amino acid residue 4-chlorothreonine (Vaillancourt et al. 2005). The fourth protein essential in syringomycin synthesis is $\mathrm{SyrC}$, which is proposed to hydrolyze 3-hydroxydodecanoyl-CoA, leading to subsequent transfer of the 3-hydroxy fatty acid to the amino group of serine bound to SyrE-M1.

For the secretion of syringomycin, studies initially focused on SyrD, a protein with homology to membrane proteins of the ABC transporter family (Quigley et al. 1993; Scholz-Schroeder et al. 2001b). A mutation in $s y r D$ resulted in a significant reduction in secretion of syringomycin and also syringopeptin and, concurrently, in a $70 \%$ reduction in virulence on cherry fruit. However, the $s y r D$ mutation did not lead to a complete loss of CLP secretion. Kang and Gross (2005) recently discovered an additional efflux system, designated PseABC, located at the left border of the syr-syp genomic island of P. syringae pv. syringae $\mathrm{B} 301 \mathrm{D}$ (Fig. 1). This tripartite transporter system, with homology to the resistance-nodulation-cell division (RND) efflux system of Ralstonia solanacearum, was shown to be involved in syringomycin and syringopeptin secretion. Also, in B. subtilis, an "RND-like" gene, designated yerP, was shown to be at least partially involved in efflux of surfactin (Tsuge et al. 2001). Interestingly, expression of yerP was not induced by surfactin, but associated with the growth phase (late logarithmic) of the producing strain. Furthermore, YerP also appeared to play a role in resistance of $B$. subtilis to other antibiotics, including acriflavine (Tsuge et al. 2001). Although a role of PseABC of $P$. syringae pv. syringae in resistance to acriflavine could not be demonstrated, heterologous expression of the pseABC genes in a drug-supersensitive mutant of $E$. coli did result in a significant increase in resistance to acriflavine and other antibiotics, supporting their functional relationship with RND-type transporter genes (Kang and Gross 2005).

Based on the unusual and nonlinear genetic organization of the synthetic template of syringomycin and the templates of several other nonribosomal peptide antibiotics (Finking and Marahiel 2004), Guenzi and associates (1998a) postulated that, for the coordinated transcription of the enzyme subunits, individual modules can be dissociated without affecting CLP synthesis at both the qualitative and quantitative level. To further test this hypothesis, Guenzi and associates (1998b) designed two mutants of surfactin-producing $B$. subtilis. In one mutant, the operon structure of the surfactin synthetic template was altered by integration of a constitutive promoter; whereas, in the other mutant, the thioesterase domain was physically dissociated from the third amino acid binding domain and expressed independently. The results showed that both mutants produced surfactin at levels comparable with the wild-type strain (Guenzi et al. 1998b). These studies indicated that domain-domain inter- actions rather than coordinated transcription and translation are essential for the correct assembly and activity of the NRPSs.

Substrate selection and selectivity-conferring elements of NRPSs. Comparative analysis of multiple NRPS sequences has shown that several of the modules harbor conserved motifs that allow the prediction of the sequence and configuration of the amino acids in the peptide moiety of the CLP molecule. A number of studies and reviews have addressed this issue in detail from a fundamental scientific perspective and also because it provides a means for targeted alteration of the structure and activity spectrum and, ultimately, enables the design of artificial nonribosomal peptide products (Challis et al. 2000; Gruenewald et al. 2004; Lautru and Challis 2004; Stachelhaus et al. 1999). One of the key questions in this context is how NRPSs select from the wide variety of precursors to be incorporated into the final CLP molecule (Lautru and Challis 2004). Most of the studies have focused on the selectivity-conferring codes within the adenylation (A) domains, because these domains select the amino acids and are regarded as the "gatekeeper" units of the repeated modules (Stachelhaus et al. 1999). Following the elucidation of the crystal structure of the phenylalanine-activating A domain (PheA) of gramicidin-S-synthetase from B. brevis (Conti et al. 1997), Stachelhaus and associates (1999) compared the amino acid residues of a large number of A domains from prokaryotic and eukaryotic origins with those lining the binding pocket of PheA. The in silico analyses provided a large number of signature sequences within A domains that allowed a prediction of the amino acid composition of the peptide moiety. This information, supplemented with new sequence data, has resulted in the design of web-based interfaces for analysis of NRPS sequences and polyketide (PKS) synthetase genes (Ansari et al. 2004; Challis et al. 2000). In addition to in silico analyses, Stachelhaus and associates (1999) provided experimental evidence for the specificity-conferring codes of A domains within NRPSs by introducing mutations in PheA, which led to the activation of L-Leu instead of phenylalanine. This and other studies also revealed that the same amino acid can be activated by A domains with different predicted selectivity pocket residues, which suggests some level of degeneracy in substrate recognition (Challis et al. 2000; Lautru and Challis 2004; Stachelhaus et al. 1999). Furthermore, certain signature sequences in the A domains contain so-called "wobble-like" positions which can lead to flexibility in amino acid usage (Stachelhaus et al. 1999). In other words, the signature sequences of A domains permit, to some degree, the incorporation of an "incorrect" amino acid, which may explain the presence of several less abundant "isoforms" of viscosin- or amphisin-like CLPs in extracts from cell cultures of antagonistic P. fluorescens strains (De Souza et al. 2003; Nielsen et al. 2002). Also C, E, and TE domains play an important role in substrate recognition (Finking and Marahiel 2004; Lautru and Challis 2004; Linne et al. 2004; Roongsawang et al. 2005; Stein et al. 2005), although specificity studies have not been conducted as extensively as for A domains. Based on the increased availability of NRPS gene sequences of Pseudomonas and other species, the list of signature sequences specific for the various A domains now can be further expanded and will provide a valuable tool in annotation of NRPS sequences and in the prediction of the CLP structures based on genome data. This information can be exploited further for targeted alteration of CLP structures and activities via modification or exchange of NRPS modules, and for combinatorial synthesis of artificial nonribosomal peptide products (Gruenewald et al. 2004; Lautru and Challis 2004).

\section{Regulation.}

Compared with our understanding of the biosynthesis of CLPs in Pseudomonas and other bacterial genera, relatively 
little is known about the genetic network involved in the perception of external factors (abiotic and biotic) and the signal transduction pathways that drive transcription of the CLP biosynthetic genes. A number of studies have focused on the effects of abiotic conditions (e.g., temperature, $\mathrm{pH}$, and oxygen), nutritional factors (e.g., carbon and nitrogen sources and trace elements), and plant signal molecules (glycosides and phenolics) on CLP production in Pseudomonas spp. (Bender et al. 1999; Bender and Scholz-Schroeder 2004; Nybroe and Sørensen 2004). This section focuses primarily on CLP regulatory genes and mechanisms identified so far for plant-associated Pseudomonas spp.

Similar to regulatory mechanisms identified for CLP production in Bacillus spp. (Duitman 2003; Sullivan 1998), two-component systems and cell density also play a key role in the regulation of CLP production in Pseudomonas spp. (Table 2). For several CLPs, including syringomycin (Bender et al. 1999; Willis and Kinscherf 2004), amphisin (Koch et al. 2002), putisolvin I and II (Dubern et al. 2005), massetolide A, and viscosin (I. de Bruijn and J. M. Raaijmakers, personal communication), the GacS/GacA two-component regulatory system appears to serve as a master switch; mutants disrupted in either one of the two genes are deficient in CLP production. Although the GacA/GacS system has been the subject of numerous studies (Heeb and Haas 2001), very little still is known about signals that serve as a trigger. Studies by Koch and associates (2002) with antagonistic Pseudomonas DSS73 elegantly demonstrated that exudates of sugar beet seed contain triggers for amphisin production and that the putative signal transmission requires a functional $\mathrm{GacS}$ protein. The active trigger compound in the seed exudates was heat stable and could be removed by dialysis; therefore, Koch and associates (2002) suggested that small organic molecules are involved. To our knowledge, the identity of these small organic molecules has not yet been resolved.

Several CLP regulatory genes that act downstream of the $\mathrm{GacA} / \mathrm{GacS}$ system have been identified. One of these genes is salA from $P$. syringae pv. syringae strains B301D and B728a. A salA mutant of strain B301D failed to produce syringomycin and was significantly reduced in virulence on cherry fruit $(\mathrm{Lu}$ et al. 2002). SalA is positively regulated by gacA and gacS, and overexpression of salA in a gacS mutant of strain B728a restored syringomycin production (Kitten et al. 1998). SalA contains a helix-turn-helix DNA binding motif and shares homology with members of the LuxR family of regulatory proteins (Lu et al. 2002). SalA activates the expression of syrB1 (Kitten et al. 1998) and $s y r F$, another LuxR-type regulatory gene involved in syringomycin synthesis (Lu et al. 2002). To further identify the members of the SalA regulon, $\mathrm{Lu}$ and associates (2005) designed an oligonucleotide microarray representing genes in the syr-syp genomic island as well as genes involved in the Hrp type III secretion system, phytohormone synthesis, siderophore and syringolin production, quorum sensing, and global regulation, including gacS, gacA, rpoN, and rpoS. Comparative analysis of the transcription profiles of a salA mutant and the wild-type strain B301D showed that genes involved in the synthesis, secretion, and regulation of syringomycin and syringopeptin were upregulated by the salA gene. No significant effects were observed for the genes located outside the syr-syp genomic island, except for the $s y l D$ gene, which is involved in syringolin synthesis ( $\mathrm{Lu}$ et al. 2005). This "genome-wide" study serves as an excellent model to further elucidate regulatory elements and networks in CLP synthesis in other Pseudomonas spp.

DnaK is another gene that is positively regulated by the $\mathrm{GacA} / \mathrm{GacS}$ system and involved in regulation of CLP synthesis in $P$. putida (Dubern et al. 2005). In a dnaK mutant of strain
PCL1445, production of putisolvin I and II was strongly reduced. Given that DnaK is a member of the Hsp70 heat shock protein family, Dubern and associates (2005) subsequently investigated the role of temperature on putisolvin production. Their results showed that putisolvin production is upregulated at low temperatures and that $d n a K$ is required for putisolvin production at low temperatures. Sequencing both up- and downstream of the dnaK gene further led to the identification of two other genes, dnaJ and grpE, that both adversely affected the synthesis of putisolvin I and II. Although the exact role of these three genes in regulation of putisolvin synthesis is not yet known, the authors speculated that they may be required for the proper folding or activity of other positive regulators of the putisolvin synthetic gene $p s o A$. Two other possible mechanisms proposed were interaction of the DnaK complex with the $\operatorname{rpoS}$ encoded sigma factor $\sigma^{\mathrm{s}}$, or the requirement of the DnaK complex for proper assembly of the peptide synthetase complex.

In addition to two-component regulation, cell density plays an important role in global regulation of CLP production in Pseudomonas spp. For many antagonistic $P$. fluorescens strains, CLP production occurs in the late exponential or stationary growth phase, but the underlying molecular mechanisms are far from being understood. In this context, Nybroe and Sørensen (2004) emphasized that, although CLP production is affected by the growth phase and nutritional conditions that lead to increased growth, the specific impact of these factors may differ considerably among strains. Quorum sensing via $N$ acyl homoserine lactones ( $N$-AHL) does not appear to play a role in amphisin and syringomycin production (Andersen et al. 2003; Kinscherf and Willis 1999; Quinones et al. 2005). Studies with antagonistic $P$. fluorescens R1SS101 indicated that $N$ AHL-mediated quorum sensing does not seem to be involved in massetolide A production (I. de Bruijn and J. M. Raaijmakers, personal communication). For the plant-pathogenic $P$. fluorescens strain 5064, recent studies by Cui and associates (2005) provided, for the first time, evidence for $N$-AHL-mediated quorum sensing in viscosin synthesis. Screening of a mutant collection of strain 5064 resulted in the identification of six mutants affected in quorum sensing signal (QSS) production. The QSS was identified as $N$-3-acyl-hydroxyoctanoyl-HSL, and addition of QSS extracts or the synthetic signal molecule restored viscosin synthesis in the mutant. Cui and associates (2005) also observed that the mutation did not lead to a complete blockage in $\mathrm{N}$-AHL expression and they speculated that there may be more than one quorum sensing system in strain 5064. Although the sequences of the genes involved in quorum sensing-mediated viscosin synthesis in strain 5064 were not described in this study (Cui et al. 2005), they may provide a useful tool to assess the presence (or absence) of homologues in other CLP-producing Pseudomonas strains.

In addition to two-component regulatory systems and cell density, Kinscherf and Willis (2002) showed that the gidA gene is involved in global regulation of syringomycin and syringopeptin synthesis in $P$. syringae. Next to the inability to produce CLPs, mutations in gidA (glucose-inhibited division) affected a variety of other phenotypes, including pyoverdine synthesis and surface motility on low-agar media. As was shown for gacS mutants of $P$. syringae, overexpression of salA restored syringomycin synthesis in gidA mutants, suggesting that gidA plays a role in salA regulation (Kinscherf and Willis 2002). Finally, analyses of regions physically linked to the CLP synthetic templates revealed a number of other interesting regulatory genes (Table 2). For syringomycin, these include the phosphate-regulated gene $\operatorname{syr} P$ (Fig. 1) and yet another LuxR-type gene syrG, although their exact roles remain to be determined (Bender and Scholz-Schroeder 2004). 


\section{Concluding remarks.}

Based on this survey, we conclude that CLPs produced by plant-associated Pseudomonas spp. are enormously diverse, both structurally and in terms of their biological activity. Although a number of regulatory genes have been identified, the understanding of the regulatory networks involved in CLP synthesis by plant-associated Pseudomonas spp. is still in its infancy. Therefore, identification of genes and mechanisms involved in perception and signal transduction is a major challenge for the near future. Also, the synthesis of the fatty acid moiety of the CLP molecule has received little attention. At present, many other specific questions remain to be addressed. For example, which external racemases in Pseudomonas spp. play a role in epimerization of the amino acids in the CLP peptide moiety? Which other natural roles and modes of action can be assigned to CLPs? How can we modulate, both quantitatively and qualitatively, in situ production of CLPs by antagonistic and pathogenic Pseudomonas spp.? Is regulation of CLP synthesis fundamentally different between pathogenic and antagonistic Pseudomonas spp.? Significant advances in the analyses and mining of whole genome sequences, the design of microarrays, and developments in metabolomics and proteomics will enable a better understanding of the synthesis, regulation, and activity of CLPs produced by Pseudomonas and other bacterial genera.

\section{ACKNOWLEDGMENTS}

This work is supported financially by the Dutch Technology Foundation (STW), the applied science division of NWO, and by the Royal Netherlands Academy of Arts and Science. We are grateful to D. Gross for critically reviewing this manuscript and for his valuable suggestions.

\section{LITERATURE CITED}

Andersen, J. B., Koch, B., Nielsen, T. H., Sørensen, D., Hansen, M., Nybroe, O., Christophersen, C., Sørensen, J., Molin, S., and Givskov, M. 2003. Surface motility in Pseudomonas sp. DSS73 is required for efficient biological containment of the root-pathogenic microfungi Rhizoctonia solani and Pythium ultimum. Microbiology 149:37-46.

Ansari, M. Z., Yadav, G., Gokhale, R. S., and Mohanty, D. 2004. NRPSPKS: A knowledge-based resource for analysis of NRPS/PKS megasynthases. Nucleic Acids Res. 32:W405-413.

Bais, H. P., Fall, R., and Vivanco, J. M. 2004. Biocontrol of Bacillus subtilis against infection of Arabidopsis roots by Pseudomonas syringae is facilitated by biofilm formation and surfactin production. Plant Physiol. 134:307-319.

Ballio, A., Barra, D., Bossa, F., Collina, A., Grgurina, I., Marino, G., Moneti, G., Paci, M., Pucci, P., Segre, A., and Simmaco, M. 1991. Syringopeptins, new phytotoxic lipodepsipeptides of Pseudomonas syringae pv. syringae. FEBS (Fed. Eur. Biol. Soc.) Lett. 291:109-112.

Ballio, A., Bossa, F., Camoni, L., Di Giorgio, D., Flamand, M. C., Maraite, H., Nitti, G., Pucci, P., and Scaloni, A. 1996. Structure of fuscopeptins, phytotoxic metabolites of Pseudomonas fuscovaginae. FEBS (Fed. Eur. Biol. Soc.) Lett. 381:213-216.

Bare, S., Coiro, V. M., Scaloni, A., Di Nola, A., Paci, M., Segre, A. L., and Ballio, A. 1999. Conformations in solution of the fuscopeptins-phytotoxic metabolites of Pseudomonas fuscovaginae. Eur. J. Biochem. 266:484-492.

Bender, C. L., Alarcon-Chaidez, F., and Gross, D. C. 1999. Pseudomonas syringae phytotoxins: Mode of action, regulation, and biosynthesis by peptide and polyketide synthetases. Microbiol. Mol. Biol. Rev. 63:266-292.

Bender, C. L., and Scholz-Schroeder, B. K. 2004. New insights into the biosynthesis, mode of action, and regulation of syringomycin, syringopeptin, and coronatine. Pages 125-158 in: Pseudomonas Vol. 2, Virulence and Gene Regulation. J.-L. Ramos, ed. Kluwer Academic/Plenum Publishers, New York, U.S.A.

Braun, P. G., Hildebrand, P. D., Ells, T. C., and Kobayashi, D. Y. 2001. Evidence and characterization of a gene cluster required for the production of viscosin, a lipopeptide biosurfactant, by a strain of Pseudomonas fluorescens. Can. J. Microbiol. 47:294-301.

Buber, E., Stindl, A., Acan, N. L., Kocagoz, T., and Zocher, R. 2002. Antimycobacterial activity of lipodepsipeptides produced by Pseudomonas syringae pv. syringae B359. Nat. Prod. Lett. 16:419-423.
Burke, T. Jr., Chandrasekhar, B., and Knight, M. 1999. Analogs of viscosin and uses thereof. U.S. Patent Number 5,965,524.

Challis, G. L., and Naismith, J. H. 2004. Structural aspects of non-ribosomal peptide biosynthesis. Curr. Opin. Struct. Biol. 14:748-756.

Challis, G. L., Ravel, J., and Townsend, C. A. 2000. Predictive, structurebased model of amino acid recognition by nonribosomal peptide synthetase adenylation domains. Chem. Biol. 7:211-224.

Coiro, V. M., Segre, A. L., Di Nola, A., Paci, M., Grottesi, A., Veglia, G., and Ballio, A. 1998. Solution conformation of the Pseudomonas syringae MSU $16 \mathrm{H}$ phytotoxic lipodepsipeptide Pseudomycin A determined by computer simulations using distance geometry and molecular dynamics from NMR data. Eur. J. Biochem. 257:449-456.

Compant, S., Duffy, B., Nowak, J., Clement, C., and Barka, E. A. 2005. Use of plant growth-promoting bacteria for biocontrol of plant diseases: Principles, mechanisms of action, and future prospects. Appl. Environ. Microbiol. 71:4951-4959.

Conti, E., Stachelhaus, T., Marahiel, M. A., and Brick, P. 1997. Structural basis for the activation of phenylalanine in the non-ribosomal biosynthesis of gramicidin S. EMBO (Eur. Mol. Biol. Organ.) J. 16:4174-4183.

Cui, X., Harling, R., Mutch, P., and Darling, D. 2005. Identification of N3-hydroxyoctanoyl-homoserine lactone production in Pseudomonas fluorescens 5064, pathogenic to broccoli, and controlling biosurfactant production by quorum sensing. Eur. J. Plant Pathol. 111:297-308.

Dalla Serra, M., Fagiuoli, G., Nordera, P., Bernhart, I., Della Volpe, C., Di Giorgio, D., Ballio, A., and Menestrina, G. 1999. The interaction of lipodepsipeptide toxins from Pseudomonas syringae pv. syringae with biological and model membranes: A comparison of syringotoxin, syringomycin, and two syringopeptins. Mol. Plant-Microbe Interact. 12:391-400.

De Souza, J. T., De Boer, M., De Waard, P., Van Beek, T. A., and Raaijmakers, J. M. 2003. Biochemical, genetic, and zoosporicidal properties of cyclic lipopeptide surfactants produced by Pseudomonas fluorescens. Appl. Environ. Microbiol. 69:7161-7172.

Dubern, J.-F., Lagendijk, E. L., Lugtenberg, B. J. J., and Bloemberg, G. V. 2005. The heat shock genes $d n a K, d n a J$, and $\operatorname{grp} E$ are involved in regulation of putisolvin biosynthesis in Pseudomonas putida PCL1445. J. Bacteriol. 187:5967-5976.

Dufour, S., Deleu, M., Nott, K., Wathelet, B., Thonart, P., and Paquot, M. 2005. Hemolytic activity of new linear surfactin analogs in relation to their physico-chemical properties. Biochim. Biophys. Acta. 1726:87-95

Duitman, E. H. 2003. Nonribosomal peptide synthesis in Bacillus subtilis. Ph.D. thesis, University of Groningen, Groningen, The Netherlands.

El Sayed, K. A., Bartyzel, P., Shen, X. Y., Perry, T. L., Kjawiony, J. K., and Hamann, M. T. 2000. Marine natural products as anti-tuberculosis agents. Tetrahedron 56:949-953.

Emanuele, M. C., Scaloni, A., Lavermicocca, P., Jacobellis, N. S., Camoni, L., Di Giorgio, D., Pucci, P., Paci, M., Segre, A., and Ballio, A. 1998. Corpeptins, new bioactive lipodepsipeptides from cultures of Pseudomonas corrugata. FEBS (Fed. Eur. Biol. Soc.) Lett. 433:317.

Feil, H., Feil, W. S., Chain, P., Larimer, F., Dibartolo, G., Copeland, A., Lykidis, A., Trong, S., Nolan, M., Goltsman, E., Thiel, J., Malfatti, S., Loper, J. E., Lapidus, A., Detter, J. C., Land, M., Richardson, P. M., Kyrpides, N. C., Ivanova, N., and Lindow, S. E. 2005. Comparison of the complete genome sequences of Pseudomonas syringae pv. syringae B728a and pv. tomato DC3000. Proc. Natl. Acad. Sci. U.S.A. 102:11064-11069.

Finking, R., and Marahiel, M. A. 2004. Biosynthesis of nonribosomal peptides. Annu. Rev. Microbiol. 58:453-488.

Fogliano, V., Ballio, A., Gallo, M., Woo, S., Scala, F., and Lorito, M. 2002. Pseudomonas lipodepsipeptides and fungal cell wall-degrading enzymes act synergistically in biological control. Mol. Plant-Microbe Interact. 15:323-333.

Gerard, J., Lloyd, R., Barsby, T., Haden, P., Kelly, M. T., and Andersen, R. J. 1997. Massetolides A-H, antimycobacterial cyclic depsipeptides produced by two pseudomonads isolated from marine habitats. J. Nat. Prod. 60:223-229.

Gewolb, J. 2002. Bioengineering. Working outside the protein-synthesis rules. Science 295:2205-2207.

Godfrey, S. A. C., Marshall, J. W., and Klena, J. D. 2001. Genetic characterization of Pseudomonas 'NZ17-a novel pathogen that results in a brown blotch disease of Agaricus bisporus. J. Appl. Microbiol. 91:412-420.

Grewal, S. I. S., Han, B., and Johnstone, K. 1995. Identification and characterization of a locus which regulates multiple functions in Pseudomonas tolaasii, the cause of brown blotch disease of Agaricus bisporus. J. Bacteriol. 177:4658-4668.

Grgurina, I., Barca, A., Cervigni, S., Gallo, M., Scaloni, A., and Pucci, P. 1994. Relevance of chlorine-substituent for the antifungal activity of syringomycin and syringotoxin, metabolites of the phytopathogenic bacterium Pseudomonas syringae pv. syringae. Experientia 50:130-133.

Gruenewald, S., Mootz, H. D., Stehmeier, P., and Stachelhaus, T. 2004. In vivo production of artificial nonribosomal peptide products in the het- 
erologous host Escherichia coli. Appl. Environ. Microbiol. 70:3282-3291.

Guenzi, E., Galli, G., Grgurina, I., Gross, D. C., and Grandi, G. 1998a. Characterization of the syringomycin synthetase gene cluster. A link between prokaryotic and eukaryotic peptide synthetases. J. Biol. Chem. 273:32857-32863.

Guenzi, E., Galli, G., Grgurina, I., Pace, E., Ferranti, P., and Grandi, G. 1998b. Coordinate transcription and physical linkage of domains in surfactin synthetase are not essential for proper assembly and activity of the multienzyme complex. J. Biol. Chem. 273:14403-14410.

Haas, D., and Défago, G. 2005. Biological control of soil-borne pathogens by fluorescent pseudomonads. Nat. Rev. Microbiol. 3:307-319.

Hansen, M., Thrane, C., Olsson, S., and Sorensen, J. 2000. Confocal imaging of living fungal hyphae challenged with the fungal antagonist viscosinamide. Mycologia 92:216-221.

Heeb, S., and Haas, D. 2001. Regulatory roles of the GacS/GacA twocomponent system in plant-associated and other gram-negative bacteria. Mol. Plant-Microbe Interact. 14:1351-1363.

Henriksen, A., Anthoni, U., Nielsen, T. H., Sorensen, J., Christophersen, C., and Gajhede, M. 2000. Cyclic lipoundecapeptide tensin from Pseudomonas fluorescens strain 96.578. Acta Crystal. 56:113-115.

Hildebrand, P. D., Braun, P. G., McRae, K. B., and Lu, X. 1998. Role of the biosurfactant viscosin in broccoli head rot caused by a pectolytic strain of Pseudomonas fluorescens. Can. J. Plant Pathol. 20:296-303.

Hrabak, E. M., and Willis, D. K. 1992. The lemA gene required for pathogenicity of Pseudomonas syringae pv. syringae on bean is a member of a family of 2-component regulators. J. Bacteriol. 174:3011-3020.

Hutchison, M. L., and Gross, D. C. 1997. Lipopeptide phytotoxins produced by Pseudomonas syringae pv. syringae: Comparison of the biosurfactant and ion channel-forming activities of syringopeptin and syringomycin. Mol. Plant-Microbe Interact. 10:347-354.

Hutchison, M. L., and Johnstone, K. 1993. Evidence for the involvement of the surface-active properties of the extracellular toxin tolaasin in the manifestation of brown blotch disease symptoms by Pseudomonas tolaasii on Agaricus bisporus. Physiol. Mol. Plant Pathol. 42:373-384.

Hutchison, M. L., Tester, M. A., and Gross, D. C. 1995. Role of biosurfactant and ion channel-forming activities of syringomycin in transmembrane ion flux: A model for the mechanism of action in the plant-pathogen interaction. Mol. Plant-Microbe Interact. 8:610-620.

Kang, H., and Gross, D. C. 2005. Characterization of a resistance-nodulation-cell division transporter system associated with the syr-syp genomic island of Pseudomonas syringae pv. syringae. Appl. Environ. Microbiol. 71:5056-5065.

Kinscherf, T. G., and Willis, D. K. 1999. Swarming by Pseudomonas syringae $\mathrm{B} 728$ a requires gacS (lemA) and gacA but not the acyl-homoserine lactone biosynthetic gene ahlI. J. Bacteriol. 181:4133-4136.

Kinscherf, T. G., and Willis, D. K. 2002. Global regulation by gidA in Pseudomonas syringae. J. Bacteriol. 184:2281-2286.

Kitten, T., Kinscherf, T. G., McEvoy, J. L., and Willis, D. K. 1998. A newly identified regulator is required for virulence and toxin production in Pseudomonas syringae. Mol. Microbiol. 28:917-929.

Koch, B., Nielsen, T. H., Sorensen, D., Andersen, J. B., Christophersen, C., Molin, S., Givskov, M., Sorensen, J., and Nybroe, O. 2002. Lipopeptide production in Pseudomonas sp. strain DSS73 is regulated by components of sugar beet seed exudate via the Gac two-component regulatory system. Appl. Environ. Microbiol. 68:4509-4516.

Koumoutsi, A., Chen, X. H., Henne, A., Liesegang, H., Hitzeroth, G., Franke, P., Vater, J., and Borriss, R. 2004. Structural and functional characterization of gene clusters directing nonribosomal synthesis of bioactive cyclic lipopeptides in Bacillus amyloliquefaciens strain FZB42. J. Bacteriol. 186:1084-1096.

Kracht, M., Rokos, H., Ozel, M., Kowall, M., Pauli, G., and Vater, J. 1999. Antiviral and hemolytic activities of surfactin isoforms and their methyl ester derivatives. J. Antibiot. 52:613-619.

Kuiper, I., Lagendijk, E. L., Pickford, R., Derrick, J. P., Lamers, G. E., Thomas-Oates, J. E., Lugtenberg, B. J., and Bloemberg, G. V. 2004. Characterization of two Pseudomonas putida lipopeptide biosurfactants, putisolvin I and II, which inhibit biofilm formation and break down existing biofilms. Mol. Microbiol. 51:97-113.

Lautru, S., and Challis, G. L. 2004. Substrate recognition by nonribosomal peptide synthetase multi-enzymes. Microbiology 150:1629-1636.

Lavermicocca, P., Iacobellis, N. S., Simmaco, M., and Graniti, A. 1997. Biological properties and spectrum of activity of Pseudomonas syringae pv. syringae toxins. Physiol. Mol. Plant Pathol. 50:129-140.

Leclère, V., Bechet, M., Adam, A., Guez, J.-S., Wathelet, B., Ongena, M. Thonart, P., Gancel, F., Chollet-Imbert, M., and Jacques, P. 2005. Mycosubtilin overproduction by Bacillus subtilis BBG100 enhances the organism's antagonistic and biocontrol activities. Appl. Environ. Microbiol. 71:4577-4584

Li, Y. Q., Sun, Z. L., Zhuang, X. F., Xu, L., Chen, S. F., and Li, M. Z. 2003. Research progress on microbial herbicides. Crop Prot. 22:247-252.
Lindow, S. E., and Brandl, M. T. 2003. Microbiology of the phyllosphere. Appl. Environ. Microbiol. 69:1875-1883.

Lindum, P. W., Anthoni, U., Christophersen, C., Eberl, L., Molin, S., and Givskov, M. 1998. N-Acyl-L-homoserine lactone autoinducers control production of an extracellular lipopeptide biosurfactant required for swarming motility of Serratia liquefaciens MG1. J. Bacteriol. 180:6384-6388.

Linne, U., Doekel, S., and Marahiel, M. A. 2001. Portability of epimerization domain and role of peptidyl carrier protein on epimerization activity in nonribosomal peptide synthetases. Biochemistry 40:15824-15834

Linne, U., Schwarzer, D., Schroeder, G. N., and Marahiel, M. A. 2004 Mutational analysis of a type II thioesterase associated with nonribosomal peptide synthesis. Eur. J. Biochem. 271:1536-1545.

Lu, S. E., Scholz-Schroeder, B. K., and Gross, D. C. 2002. Characterization of the salA, syrF, and $\operatorname{syr} G$ regulatory genes located at the right border of the syringomycin gene cluster of Pseudomonas syringae pv. syringae. Mol. Plant-Microbe Interact. 15:43-53.

Lu, S. E., Soule, J. D., and Gross, D. C. 2003. Characterization of the $\arg A$ gene required for arginine biosynthesis and syringomycin production by Pseudomonas syringae pv. syringae. Appl. Environ. Microbiol. 69:7273-7280.

Lu, S. E., Wang, N., Wang, J., Chen, Z. J., and Gross, D. C. 2005. Oligonucleotide microarray analysis of the salA regulon controlling phytotoxin production by Pseudomonas syringae pv. syringae. Mol. PlantMicrobe Interact. 18:324-333.

Lugtenberg, B. J. J., Dekkers, L., and Bloemberg, G. V. 2001. Molecular determinants of rhizosphere colonization by Pseudomonas. Annu. Rev. Phytopathol. 39:461-490.

Marahiel, M. A., Stachelhaus, T., and Mootz, H. D. 1997. Modular peptide synthetases involved in nonribosomal peptide synthesis. Chem. Rev. 97:2651-2673

Mercado, T. I., and Colon-Whitt, A. 1982. Lysis of Trypanosoma cruzi by Pseudomonas fluorescens. Antimicrob. Agents Chemother. 22:10511057

Mireles, J. R., Toguchi, A., and Harshey, R. M. 2001. Salmonella enterica serovar typhimurium swarming mutants with altered biofilm-forming abilities: Surfactin inhibits biofilm formation. J. Bacteriol. 183:58485854

Monti, S. M., Gallo, M., Ferracane, R., Borrelli, R. C., Ritieni, A., Greco, M. L., Graniti, A., and Fogliano, V. 2001. Analysis of bacterial lipodepsipeptides by matrix-assisted laser desorption/ionisation time-of-flight and high-performance liquid chromatography with electrospray mass spectrometry. Rapid Commun. Mass Spectrom. 15:623-628.

Morikawa, M., Daido, H., Takao, T., Murata, S., Shimonishi, Y., and Imanaka, T. 1993. A new lipopeptide biosurfactant produced by Arthrobacter sp. strain MIS38. J. Bacteriol. 175:6459-6466.

Morikawa, M., Hirata, Y., and Imanaka, T. 2000. A study on the structurefunction relationship of lipopeptide biosurfactants. Biochim. Biophys. Acta 1488:211-218.

Mott, K. A., and Takemoto, J. Y. 1989. Syringomycin, a bacterial phytotoxin, closes stomata. Plant Physiol. 90:1435-1439.

Neu, T. R. 1996. Significance of bacterial surface-active compounds in interaction of bacteria with interfaces. Microbiol. Rev. 60:151-166.

Nielsen, T. H., Christophersen, C., Anthoni, U., and Sorensen, J. 1999. Viscosinamide, a new cyclic depsipeptide with surfactant and antifungal properties produced by Pseudomonas fluorescens DR54. J. Appl. Microbiol. 87:80-90

Nielsen, T. H., Sorensen, D., Tobiasen, C., Andersen, J. B., Christophersen, C., Givskov, M., and Sorensen, J. 2002. Antibiotic and biosurfactant properties of cyclic lipopeptides produced by fluorescent Pseudomonas spp. from the sugar beet rhizosphere. Appl. Environ. Microbiol. 68:3416-3423.

Nielsen, T. H., and Sorensen, J. 2003. Production of cyclic lipopeptides by Pseudomonas fluorescens strains in bulk soil and in the sugar beet rhizosphere. Appl. Environ. Microbiol. 69:861-868.

Nielsen, T. H., Nybroe, O., Koch, B., Hansen, M., and Sorensen, J. 2005. Genes involved in cyclic lipopeptide production are important for seed and straw colonization by Pseudomonas sp strain DSS73. Appl. Environ. Microbiol. 71:4112-4116.

Nybroe, O., and Sorensen, J. 2004. Production of cyclic lipopeptides by fluorescent pseudomonads. Pages 147-172 in: Pseudomonas, Biosynthesis of Macromolecules and Molecular Metabolism. J.-L. Ramos, ed., Kluwer Academic/Plenum Publishers, New York, U.S.A.

O'Toole, G., Kaplan, H. B., and Kolter, R. 2000. Biofilm formation as microbial development. Annu. Rev. Microbiol. 54:49-79.

Paulsen, I. T., Press, C. M., Ravel, J., Kobayashi, D. Y., Myers, G. S. A., Mavrodi, D. V., DeBoy, R. T., Seshadri, R., Ren, Q. H., Madupu, R., Dodson, R. J., Durkin, A. S., Brinkac, L. M., Daugherty, S. C., Sullivan, S. A., Rosovitz, M. J., Gwinn, M. L., Zhou, L. W., Schneider, D. J., Cartinhour, S. W., Nelson, W. C., Weidman, J., Watkins, K., Tran, K. 
Khouri, H., Pierson, E. A., Pierson, L. S., Thomashow, L. S., and Loper J. E. 2005. Complete genome sequence of the plant commensal Pseudomonas fluorescens Pf-5. Nat. Biotechnol. 23:873-878.

Paulsen, I. T., Press, C. M., Ravel, J., Kobayashi, D. Y., Myers, G. S. A., Mavrodi, D. V., DeBoy, R. T., Seshadri, R., Ren, Q. H., Madupu, R., Dodson, R. J., Durkin, A. S., Brinkac, L. M., Daugherty, S. C., Sullivan, S. A., Rosovitz, M. J., Gwinn, M. L., Zhou, L. W., Schneider, D. J., Cartinhour, S. W., Nelson, W. C., Weidman, J., Watkins, K., Tran, K., Khouri, H., Pierson, E. A., Pierson, L. S., Thomashow, L. S., and Loper, J. E. 2006. Corrigendum: Biocontrol genome deciphered. Nat. Bioltechnol. 27 March 2006. Published online.

Pedras, M. S. C., Ismail, N., Quail, J. W., and Boyetchko, S. M. 2003. Structure, chemistry, and biological activity of pseudophomins A and B, new cyclic lipodepsipeptides isolated from the biocontrol bacterium Pseudomonas fluorescens. Phytochemistry 62:1105-1114.

Peypoux, F., Bonmatin, J. M., and Wallach, J. 1999. Recent trends in the biochemistry of surfactin. Appl. Microbiol. Biotechnol. 51:553-563.

Pieterse, C. M. J., Van Wees, S. C. M., Ton, J., Van Pelt, J. A., and Van Loon, L. C. 2002. Signaling in rhizobacteria-induced systemic resistance in Arabidopsis thaliana. Plant Biol. 4:535-544.

Quail, J. W., Ismail, N., Pedras, M. S. C., and Boyetchko, S. M. 2002. Pseudophomins A and B, a class of cyclic lipodepsipeptides isolated from a Pseudomonas species. Acta Crystallogr. Sect. C 58:268-271.

Quigley, N. B., Mo, Y. Y., and Gross, D. C. 1993. SyrD is required for syringomycin production by Pseudomonas syringae pathovar syringae and is related to a family of ATP-binding secretion proteins. Mol. Microbiol. 9:787-801

Quinones, B., Dulla, G., and Lindow, S. E. 2005. Quorum sensing regulates exopolysaccharide production, motility, and virulence in Pseudomonas syringae. Mol. Plant-Microbe Interact. 18:682-693.

Raaijmakers, J. M., Vlami, M., and de Souza, J. T. 2002. Antibiotic production by bacterial biocontrol agents. Antonie Leeuwenhoek Int. J. Gen. Mol. Microbiol. 81:537-547.

Rainey, P. B., Brodey, C. L., and Johnstone, K. 1991. Biological properties and spectrum of activity of tolaasin, a lipodepsipeptide toxin produced by the mushroom pathogen Pseudomonas tolaasii. Physiol. Mol. Plant Pathol. 39:57-70.

Rainey, P. B., Brodey, C. L., and Johnstone, K. 1993. Identification of a gene-cluster encoding 3 high-molecular-weight proteins, which is required for synthesis of tolaasin by the mushroom pathogen Pseudomonas tolaasii. Mol. Microbiol. 8:643-652.

Ramos, J.-L. 2004. Pseudomonas, Vol. 1-3. Kluwer Academic/Plenum Publishers, New York, U.S.A.

Rich, J. J., Kinscherf, T. G., Kitten, T., and Willis, D. K. 1994. Genetic evidence that the gacA gene encodes the cognate response regulator for the lemA sensor in Pseudomonas syringae. J. Bacteriol. 176:7468-7475.

Ron, E. Z., and Rosenberg, E. 2001. Natural roles of biosurfactants. Environ. Microbiol. 3:229-236.

Roongsawang, N., Hase, K., Haruki, M., Imanaka, T., Morikawa, M., and Kanaya, S. 2003. Cloning and characterization of the gene cluster encoding arthrofactin synthetase from Pseudomonas sp. MIS38. Chem. Biol. 10:869-880.

Roongsawang, N., Lim, S. P., Washio, K., Takano, K., Kanaya, S., and Morikawa, M. 2005. Phylogenetic analysis of condensation domains in the nonribosomal peptide synthetases. FEMS (Fed. Eur. Microbiol. Soc.) Microbiol. Lett. 252:143-151.

Ryu, C.-M., Hu, C.-H., Reddy, M. S., and Kloepper, J. W. 2003. Different signaling pathways of induced resistance by rhizobacteria in Arabidopsis thaliana against two pathovars of Pseudomonas syringae. New Phytol. 160:413-420.

Scaloni, A., Dalla Serra, M., Amodeo, P., Mannina, L., Vitale, R. M., Segre, A. L., Cruciani, O., Lodovichetti, F., Greco, M. L., Fiore, A., Gallo, M., D’Ambrosio, C., Coraiola, M., Menestrina, G., Granit, A., and Fogliano, V. 2004. Structure, conformation and biological activity of a novel lipodepsipeptide from Pseudomonas corrugata: Cormycin A. Biochem. J. 384:25-36.

Scholz-Schroeder, B. K., Hutchison, M. L., Grgurina, I., and Gross, D. C. 2001a. The contribution of syringopeptin and syringomycin to virulence of Pseudomonas syringae pv. syringae strain B301D on the basis of sypA and syrBl biosynthesis mutant analysis. Mol. Plant-Microbe Interact. 14:336-348.

Scholz-Schroeder, B. K., Soule, J. D., and Gross, D. C. 2003. The sypA, sypB and syp $C$ synthetase genes encode twenty-two modules involved in the nonribosomal peptide synthesis of syringopeptin by Pseudomonas syringae pv. syringae B301D. Mol. Plant-Microbe Interact. 16:271-280.

Scholz-Schroeder, B. K., Soule, J. D., Lu, S. E., Grgurina, I., and Gross, D. C. 2001b. A physical map of the syringomycin and syringopeptin gene clusters localized to an approximately $145-\mathrm{kb}$ DNA region of Pseudomonas syringae pv. syringae strain B301D. Mol. Plant-Microbe Interact. 14:1426-1435.

Sieber, S. A., and Marahiel, M. A. 2005. Molecular mechanisms underlying nonribosomal peptide synthesis: Approaches to new antibiotics. Chem. Rev. 105:715-738.

Soler-Rivas, C., Arpin, N., Olivier, J. M., and Wichers, H. J. 1999. WLIP, a lipodepsipeptide of Pseudomonas 'reactans', as inhibitor of the symptoms of the brown blotch disease of Agaricus bisporus. J. Appl. Microbiol. 86:635-641.

Sorensen, D., Nielsen, T. H., Christophersen, C., Sorensen, J., and Gajhede, M. 2001. Cyclic lipoundecapeptide amphisin from Pseudomonas sp. strain DSS73. Acta Crystallogr. 57:1123-1124.

Stachelhaus, T., Mootz, H. D., and Marahiel, M. A. 1999. The specificityconferring code of adenylation domains in nonribosomal peptide synthetases. Chem. Biol. 6:493-505.

Stein, D. B., Linne, U., and Marahiel, M. A. 2005. Utility of epimerization domains for the redesign of nonribosomal peptide synthetases. FEBS (Fed. Eur. Biol. Soc.) J. 272:4506-4520.

Sullivan, E. R. 1998. Molecular genetics of biosurfactant production. Curr. Opin. Biotechnol. 9:263-269.

Thrane, C., Harder Nielsen, T., Neiendam Nielsen, M., Sorensen, J., and Olsson, S. 2000a. Viscosinamide-producing Pseudomonas fluorescens DR54 exerts a biocontrol effect on Pythium ultimum in sugar beet rhizosphere. FEMS (Fed. Eur. Microbiol. Soc.) Microbiol. Ecol. 33:139-146.

Thrane, C., Nielsen, M. N., Sorensen, J., and Olsson, S. 2001. Pseudomonas fluorescens DR54 reduces sclerotia formation, biomass development, and disease incidence of Rhizoctonia solani causing damping-off in sugar beet. Microb. Ecol. 42:438-445.

Thrane, C., Nielsen, T. H., Nielsen, M. N., Sorensen, J., and Olsson, S. 2000b. Viscosinamide-producing Pseudomonas fluorescens DR54 exerts a biocontrol effect on Pythium ultimum in sugar beet rhizosphere. FEMS (Fed. Eur. Microbiol. Soc.) Microbiol. Ecol. 33:139-146.

Thrane, C., Olsson, S., Nielsen, T. H., and Sorensen, J. 1999. Vital fluorescent stains for detection of stress in Pythium ultimum and Rhizoctonia solani challenged with viscosinamide from Pseudomonas fluorescens DR54. FEMS (Fed. Eur. Microbiol. Soc.) Microbiol. Ecol. 30:11-23.

Tsuge, K., Ohata, Y., and Shoda, M. 2001. Gene yerP, involved in surfactin self-resistance in Bacillus subtilis. Antimicrob. Agents Chemother. 45:3566-3573.

Vaillancourt, F. H., Yin, J., and Walsh, C. T. 2005. From the cover: SyrB2 in syringomycin $\mathrm{E}$ biosynthesis is a nonheme FeII \{alpha\}-ketoglutarate- and O2-dependent halogenase. Proc. Natl. Acad. Sci. U.S.A. 102:10111-10116.

Vollenbroich, D., Ozel, M., Vater, J., Kamp, R. M., and Pauli, G. 1997a. Mechanism of inactivation of enveloped viruses by the biosurfactant surfactin from Bacillus subtilis. Biologicals 25:289-297.

Vollenbroich, D., Pauli, G., Ozel, M., and Vater, J. 1997b. Antimycoplasma properties and application in cell culture of surfactin, a lipopeptide antibiotic from Bacillus subtilis. Appl. Environ. Microbiol. 63:44-49.

von Dohren, H., Dieckmann, R., and Pavela-Vrancic, M. 1999. The nonribosomal code. Chem. Biol. 6:R273-R279.

Wang, N., Lu, S.-E., Yang, Q., Sze, S.-H., and Gross D.C. Identification of the syr-syp box in the promoter regions of genes dedicated to syringomycin and syringopeptin production by Pseudomonas syringae pv. syringae $\mathrm{B} 301 \mathrm{D}$. J. Bacteriol. In press.

Whipps, J. M. 2001. Microbial interactions and biocontrol in the rhizosphere. J. Exp. Bot. 52:487-511.

Willis, D. K., and Kinscherf, T. G. 2004. Global regulation in Pseudomonas syringae. Pages 223-238 in: Pseudomonas Vol. 2, Virulence and Gene Regulation. J.-L. Ramos, ed. Kluwer Academic/Plenum Publishers, New York, U.S.A.

Zhang, J. H., Quigley, N. B., and Gross, D. C. 1995. Analysis of the syrB and $\operatorname{syrC}$ genes of Pseudomonas syringae pv. syringae indicates that syringomycin is synthesized by a thiotemplate mechanism. J. Bacteriol. 177:4009-4020.

Zhang, J. H., Quigley, N. B., and Gross, D. C. 1997. Analysis of the syrP gene, which regulates syringomycin synthesis by Pseudomonas syringae pv. syringae. Appl. Environ. Microbiol. 63:2771-2778.

\section{AUTHOR-RECOMMENDED INTERNET RESOURCES}

Pseudomonas Genome Database ${ }_{\mathrm{V} 2}$ : v2.pseudomonas.com

PseudoDB database: pseudo.bham.ac.uk/ 